Çukurova Üniversitesi Eğitim Fakültesi Dergisi

Vol: 50 Numb: 2 Page: 1367-1396

https://dergipark.org.tr/tr/pub/cuefd

\title{
Investigation of Fifth Grade Students' Perceptions about the Educational Game Method \\ Emre YILDIZ $^{a^{*}}$ (ORCID ID - 0000-0001-6396-9183) \\ Ümit ŞiMŞEK ${ }^{b}$ (ORCID ID - 0000-0003-2010-9321) \\ ${ }^{a}$ Atatürk Üniversitesi, KKEF, Fen Bilgisi Eğitimi $A D$, Erzurum/Türkiye \\ ${ }^{b}$ Atatürk Üniversitesi, KKEF, Fen Bilgisi Eğitimi AD, Erzurum/Türkiye \\ CrossMark
}

\section{Article Info}

\section{DOI: $10.14812 /$ cufej.841358}

Article history:

Received $\quad 15.12 .20$

Revised 24.10.21

Accepted 29.10.21

Keywords:

Educational Game, Fifth Grade,

Perception, Reaction, View.

\section{Abstract}

This study was carried out to determine students' perceptions of the educational game method applied in teaching the subject of "Matter and Change", where they have learning problems. The case study method was used in the study. The participant group consists of six fifth grade students studying in central and rural areas of Erzurum. Unstructured observation, student diaries and semi-structured interviews were used as data collection tools. Content analysis method was used in the analysis of the data. At the end of research it was seen that the educational game method facilitates students' learning, is sufficient in terms of knowledge and concept teaching, provides meaningful learning, increases the motivation of learning by increasing interest and desire, developing a positive attitude towards the lesson, teacher and school, reduces fear and learning anxiety, improves social skills such as working together, helping each other, and tolerance. As a result, it was found that students' perceptions of the educational game method are positive.

\begin{tabular}{|c|c|}
\hline Makale & Bilgisi \\
\hline DOI: 10.14 & 812/cufej.841358 \\
\hline Makale G & çmişi: \\
\hline Geliş & 15.12 .20 \\
\hline Düzeltme & 24.10 .21 \\
\hline Kabul & 29.10 .21 \\
\hline
\end{tabular}

Anahtar Kelimeler:

Eğitsel Oyun, Beşinci Sınıf, Algı, Tepki, Görüş.

\section{incelenmesi}

Öz

$\mathrm{Bu}$ araştırma öğrencilerin, öğrenme problemleri yaşadıkları "Madde ve Değişim" konusunun öğretiminde uygulanan eğitsel oyun yöntemine yönelik algılarını belirlemek amacıyla yapılmıştır. Araştırmada durum çalışması yöntemi kullanılmıştır. Katılımcı grubunu Erzurum ili merkez ve kırsa bölgelerde öğrenim gören altı beşinci sınıf öğrencisi oluşturmaktadır. Veri toplama aracı olarak yapılandırılmamış gözlem, öğrenci günlükleri ve yarı-yapılandırılmış görüşme kullanılmıştır. Verilerin analizinde içerik analizi yöntemi kullanılmıştır. Araştırma sonucunda öğrencilerin eğitsel oyun yönteminin öğrenmelerini kolaylaştırdığı, bilgi sağama ve kavram öğretimi açısından yeterli olduğu, anlamlı öğrenmeler sağladığı, ilgi ve isteği artırarak öğrenme motivasyonunu yükselttiği, derse, öğretmene ve okula karşı olumlu tutum geliştirmeyi, korku ve öğrenme kaygısını azalttığı, birlikte çalışma, yardımlaşma, hoşgörü gibi sosyal becerileri geliştirdiği görüşünde oldukları belirlenmiştir. Sonuç olarak öğrencilerin eğitsel oyun yöntemine yönelik algılarının olumlu olduğu bulunmuştur.

\section{Introduction}

Game activities are generally considered leisure entertainment by adults. However, games are fun activities that attract the attention of individuals of all ages, arouse curiosity, participate willingly and willingly and enable them to develop in various aspects. For this reason, it can be said that games are a

* This research was produced from the first author's doctoral thesis.

This research was supported by Atatürk University 6267 BAP.

*Author: emre.yildiz@atauni.edu.tr 
necessity for individuals of all ages. Similarly, Demir and Kurt (2015) stated that games are a necessity for both children and adults today.

Games, which the Turkish Language Association defines as "talent and intelligence developing, having certain rules, fun for having a good time", have been defined in different ways by many researchers as they are a tool that is studied in many different fields and provides the individual's versatile development. According to Dönmez (1992), play; is a part of real life, which is an effective tool in learning, ensuring the physical, emotional, and social development of the individual willingly and willingly, regardless of how it is carried out with or without purpose, with rules or without rules. According to some researchers, play is a natural activity that occurs in the absence of external threats and stressors (Aamondt \& Wank, 2011), and according to some researchers, it is a pedagogical tool that helps to learn (Fleer, 2014). Game is a tool, that is described as the art of learning by many researchers (Poyraz, 2003), which relieves children of their excess energy, relaxes them, teaches social roles, prepares them for adulthood, relives the behaviors transferred from their ancestors, enables them to understand real life, gains and reinforces new skills, develops them in physical, cognitive, affective and social areas, and provides problem-solving skills. Games are classified in different ways by researchers (Hazar, 2006). Akandere (2012) analyzes games under two headings: children's games and educational games.

The educational game (EG) method is one of the active learning methods that include the use of educational games in learning environments that increase the interaction of students in a real entertainment environment and provide more effective learning to achieve educational goals (MacKenzie, 2014; Michael \& Chen, 2006). It is seen that more effective learning takes place when the learning environment is fun, and games increase the level of fun by bringing together elements such as imagination, curiosity, adventure, role-playing, strategy, sports, and challenge (Gros, 2007; Malone, Lepper, Snow \& Farr, 1987; Stewart, 2013). Educational games with central components such as visualization, exploration, and problem-solving increase learning through experimentation and creativity, especially in science (Habraken, 2004; Rieber, Luke \& Smith, 1998; Squire \& Jenkins, 2003). Play, which is a natural learning tool, enables children to learn through their own experiences (Özgür, 2000).

The EG method is an effective method that increases students' motivation to learn, increases the rate of participation in the lesson, makes the lesson, teacher, school love, improves social skills such as speaking in the group, listening, conveying thoughts, respecting different ideas, helping each other, and reducing stress and anxiety (Akandere, 2012; Bilen, 2002; Pehlivan, 2014). However, while the games are being prepared for this, the purpose of the game, the things to be done for the game, the details of the gameplay, evaluation, and development of the game should be planned (Akandere, 2012; Pehlivan, 2014). When the games are not planned well, the method has many limitations. In order to avoid such situations, the competition should be kept at a positive level, suitable for the level of the student, not having difficulties that students cannot achieve, all students should participate in the process, and the game should not be difficult and complicated for students to take (Demirel, 1999; Pehlivan, 2014).

When the studies in the literature are examined, it is seen that the studies on the EG method at the secondary school level focus on the achievement variable and it is concluded that the method is effective in increasing achievement and learning concepts (Anderson, 2008; Aymen-Peker, 2018; Boyce, 2016; Dowling, 2012; Eltem, 2018; Espinoza Morales, 2017; Folta, 2010; Gençer, 2016; Gürpınar, 2017; Harvey, 2018; Huang, 2016; Koka, 2018; Yıldız, Şimşek \& Ağdaş, 2018; Yıldız, Şimşek, \& Aras, 2016). Eltem (2018), Harvey (2018), and Peng (2009) examined the reactions and opinions of the students towards the method and concluded that there are generally positive attitudes and opinions towards the EG method. Boyce (2016), on the other hand, worked with seventh-grade students with learning disabilities and concluded that the method was effective in concept development and students exhibited positive behaviors. Şentürk (2020) concluded that the EG method supports the cognitive, affective, and social development of fourth-grade students as a results of the interviews and the student diaries conducted in the qualitative part of his research and the analysis of the data obtained from. As 
can be seen from the studies examined, the studies that examine the reactions and opinions of the students towards the method remain in the background. It is important to examine the reasons behind these developments and how the developments occur, as well as examining the effects on students' development. Therefore, in this study, students' perceptions and reasons for the EG method were examined.

When the studies in the literature are examined, it is seen that the fifth-grade students have problems such as learning difficulty, low motivation, increased learning anxiety in the "Matter and Change" unit (Yıldız, 2019), and there are misconceptions in many concepts such as heat, temperature, evaporation, etc. (Buluş Kırıkkaya \& Güllü, 2008). This research was carried out to determine the perceptions of the students towards the EG method applied in the teaching of the subject of "Matter and Change", which were found to have learning problems. Depending on this purpose, the problem statement of the research was determined as.: "What are the perceptions of the students towards the EG method applied in the "Matter and Change" unit, which was determined to have learning problems?"

\section{Method}

\section{Research Model}

The case study method was used in the research. The case study is a method in which one or more situations, groups, events, or interconnected systems are studied in detail (Glesne, 2011; McMillan, 2000). In case studies, real-life situations that cannot be controlled are studied in depth (Yin, 2003). In this study, the most appropriate method is the case study since the students' reactions to the method, their opinions about the method, and the reasons behind them are investigated without intervening in their behaviors during the application of the method. Since it was stated that using more than one data collection tool would be beneficial in this method (Gillham, 2000), data were collected through observation, diary, and interview. To increase the validity of the research results; different data sources were used, field studies were carried out in a wide period of time such as seven weeks, a field expert was informed about the study and regular feedback was received, a second researcher was included in the process, the findings were supported by direct quotations, divergent samples were determined tried not to enter into expectations and not to be prejudiced and as much as possible.

\section{Participants}

The research was carried out with six fifth-grade students studying in Erzurum city center and rural areas in the 2017-2018 academic year. Maximum variety sampling was used to determine the students. The main purpose of this sampling is to examine the problem situation in a wider framework by revealing the aspects that combine or diverge between different situations in line with the determined purpose (Johnson \& Christensen, 2014). The region of study and the success status of the student, which is thought to be effective in the reactions and opinions of the students towards the method, were taken into consideration. Accordingly, one successful, one moderately successful, and one low-achieving student was determined in both regions. While determining the students, the pretest scores applied at the beginning of the method were taken into account. Volunteering was sought in the selected students and new students with similar characteristics were selected instead of students who did not want to participate. At the beginning of the application, permission was obtained from the parents for the students to participate in the research, provided that the data obtained is only used for scientific purposes and the identity of the student is kept confidential. The students in the center were coded as C5-EG1, C5-EG2, C5-EG3, and the students in the rural were coded as R5-EG1, R5-EG2, R5-EG3.

\section{Data Collection Tools}

\section{Semi-structured interview}

A two-stage semi-structured interview was conducted to determine the views of the students on the educational game method applied and the effect of this method on solving learning problems. The first stage of the interview consisted of eight questions. The questions at this stage are aimed at determining 
the students' thoughts on how effectively they learned with the method, the positive and negative aspects of the method, its effects on entertainment, providing information, developing skills, and working individually and in groups. The second stage of the interview consisted of five questions. The questions at this stage are aimed at determining the students' thoughts on the effects of the application of the method on the subjects in which they have learning problems, on their success, motivation, anxiety, and the permanence of their knowledge.

All prepared interview questions were sent to three science education experts along with expert evaluation forms. Pilot studies were carried out by applying the questions, which were prepared by considering the opinions of the experts, to the two selected students. During the pilot studies, the comfort of the interview environment, the comfort of the students in answering the questions, the level of students' understanding of the questions, and what kind of questions could be asked to deepen the answers were examined and necessary arrangements were made for the actual interviews. After the pilot studies were completed, the data obtained were analyzed quickly and it was examined whether the questions fully met the purpose of asking.

The interviews were conducted in a room used by the school's guidance service in the central school and in a room in addition to the teachers' room in the rural school. When the students were interviewed, it was tried to get used to the environment first. During the interviews, only the researcher and the student were present in the environment. It has been explained that the answers given by the students will not be used to evaluate them, they will not affect their grades in any way, their teachers will not be aware of the answers they give, the answers they will give are not intended to evaluate their teachers, and they will only be asked questions to determine their views on the method. It was stated to the students that a voice recorder would be used during the interviews, and they were informed that the audio recordings were taken for the researcher to convert the conversations into written form, that they would not be shared with anyone, and that the real identities of the students would be hidden. Interview questions were directed to the students in order and additional questions were asked according to the answers from the students. Additional questions were asked to deepen the answers given by the students and to gather more information about the answers. The answers given by the students were repeated intermittently and confirmations were obtained. At the end of each interview, the students were asked if they had anything to add. The interviews lasted between 15-25 minutes on average. Data were collected by interviewing each student at two different times determined. At the end of the day of the interview, the records were written down and the researcher's notes about the interview were recorded in the written form.

Interview data were analyzed by the researcher at two different times. The obtained data were analyzed by a second researcher. For the first interviews, the percentage of agreement between the analyzes made by the researcher at different times was $84 \%$, and the Kappa coefficient between the analyzes made by the two researchers was calculated as .74. For the second interviews, the percentage of agreement between the analyzes made by the researcher at different times was $85 \%$, and the percentage of agreement between the analyzes made by the two researchers was calculated as $72 \%$.

\section{Unstructured observation}

Before the process related to the observations started, the opinions of the field experts were taken. The observations were carried out unstructured because the experts stated that using the observation form in the observations would limit the data, that the expectations in the behaviors would cause the students to miss different behaviors, and suggested that unstructured observations should be made.

Observations were started to be made as two hours per week in the classes of the practitioner teachers two weeks before the application started. Reasons for starting observations before execution:

- Naturalizing their behavior by allowing students and teachers to get used to the presence of a stranger in the classroom, 
- To normalize the camera recordings made in the lesson and to prevent the fake behaviors that will be exhibited due to the recordings,

- $\quad$ To describe the class, teachers, and students.

In the first two weeks of observation, classrooms, teachers, and students are depicted. Although this process is not included in the research data, it is important in terms of providing a holistic perspective in the analysis of the research data and the effect of the environment on the behaviors exhibited. In these descriptions, the physical structure of the classroom was explained in detail, the general structures of the teachers and students and the communication between them were tried to be observed in detail.

Observations were made simultaneously by the researcher and a second researcher involved in the process. At the same time, the lessons were recorded with a camera. At the beginning of each observation, the researcher briefly described himself (his feelings and thoughts, what kind of mood he had). The fact that the researcher explained himself at the beginning of the observations gave an idea about how he made the observations in the analysis part of the data. At the end of the day of the observation, the observation notes and camera records of the two researchers were examined and the observation data were recorded. Researcher notes about the observations were also added to the observation data to assist in the analysis.

Observation data were analyzed by the researcher at two different times. The data were analyzed independently by the second researcher. The percentage of agreement between the analyzes made by the researcher at different times was $77 \%$, and the percentage of agreement between the analyzes made by the two researchers was calculated as $71 \%$.

\section{Student diaries}

Students were asked to write two weekly diaries (one diary for every two lesson hours). Students were asked to write the following titles in their diaries:

- Briefly describe what you did in the lesson and how you handled the lesson.

- Explain what you learned in the lesson as far as you can remember without using any source.

- Explain what your feelings, thoughts, and attitudes were during the lesson, with reasons.

- Explain the behaviors you exhibited during the lesson with their reasons.

- Tell about your good and bad sides during the lesson.

- Explain your suggestions for the next lessons.

The directive for preparing a diary for the students was given to the students two weeks before the methods prepared by the researcher started to be applied, and it was tried to get them accustomed to writing a diary until the method application started. While writing their diaries, the students paid attention to the following points:

- Diaries should be written on A4 size white or optionally colored paper.

- Sincere, natural and everyday language should be used in the diaries and the diary should be addressed as desired.

- $\quad$ The diary can be prepared as desired using colored pencils, pictures can be drawn and stickers can be pasted. Individuals are free to decorate their diaries.

- The dairy should be written in understandable way with Turkish spelling and spelling rules.

- The diary should be written for the science lesson and the explanations outside the lesson should be avoided.

- The diary, preparation instructions should be followed and all headings mentioned in the directive should be included in the diary.

- Headings should not be considered as disconnected from each other and should be given as a whole. 
The two-week diaries before the start of the application were examined in detail, and feedbacks were prepared and shared with the practitioner teachers. Teachers shared these feedbacks with their students and helped them to write diaries in the desired format. All students were asked to write diaries and all diaries were read by the researcher, but the diaries of the students who were determined as participants were evaluated for analysis.

The data obtained from the diaries were analyzed by the researcher at two different times. A second expert was asked to analyze the data. The percentage of agreement between the analyzes made by the researcher at different times was $82 \%$, and the percentage of agreement between the analyzes made by the two researchers was calculated as $76 \%$.

\section{Data Collection}

The Practitioner's Guide was prepared by the researcher for teachers who applied the EG method in both central and rural areas. This guide consisted of general information about the EG method, the designing, rules, and playing of the educational games used in the method, activities related to the subject, assignments, and a detailed application plan for the application of the method in teaching the subject. The guide was given to the teachers who would make the application one month in advance. When the teachers examined the guide, two seminars were organized by the researcher and the actions that the teachers would take in the process were explained in detail. In addition, the actions to be taken every week were regularly reminded to the teachers. The researcher participated in the process only as an observer and all the practices in the classroom were carried out by the teacher. Educational games designed for teaching the subject were applied by the teacher, the activities were performed by gamification, and the assignments were given and evaluated at the specified times. In this way, the application was completed in 26 lesson hours. Observation and diary data were taken throughout the process, and interviews were conducted in two stages at the end of the process.

The research was carried out within the scope of the permission of Erzurum Provincial Directorate of National Education, dated 06.10.2017 and numbered 36648235-605.01.E.16089927. The research approval form was signed by the principal of the school where the research was carried out and the science teacher of the class. Atatürk University Social and Human Sciences Ethics Committee's document dated 26.10.2016 and numbered 48553601-000-E.1600268066 shows that the research was carried out in accordance with ethical rules.

\section{Data Analysis}

The analysis of the data was carried out with the content analysis method. Content analysis is a technique that allows researchers to examine human behavior indirectly through the analysis of its communication with them. It is a technique usually, but not always, used in qualitative data analysis, which allows researchers to discover, meaningfully reveal, and in-depth analyze the messages of data obtained from any source such as audio recordings, video recordings or pictures, etc., written documents in communication. (Fraenkel, Wallen \& Hyun, 2011; Neuman, 2014). The steps given in Figure 1 were followed in the analysis of the data with content analysis. 


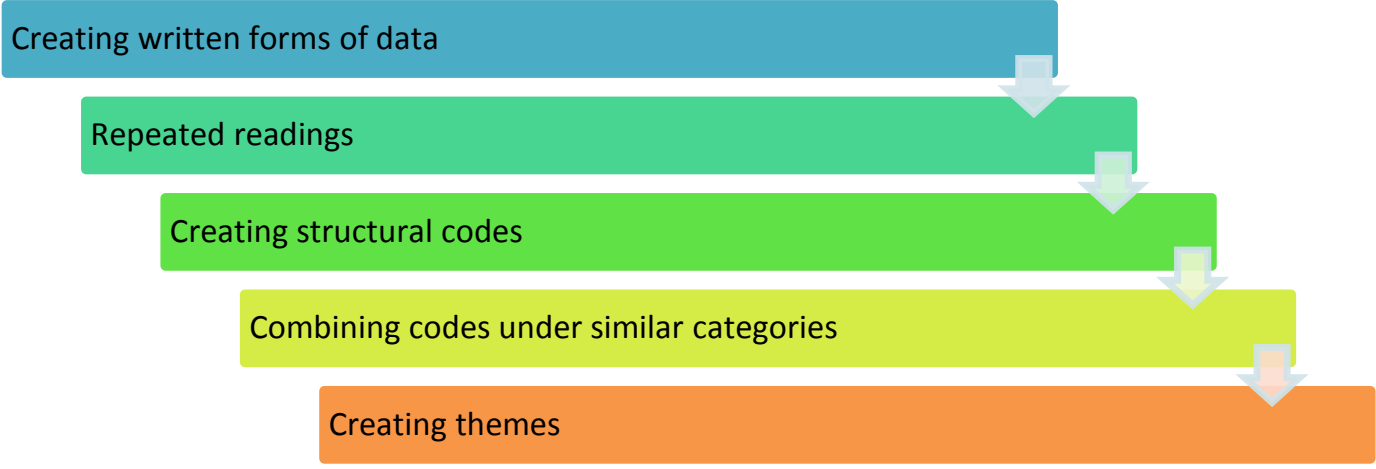

Figure 1. Processes Followed in Content Analysis

At the end of the day the observations were made, the observation reports of the researcher, the observation reports of the second researcher, and the camera records were examined and cleared in the computer environment. At the end of the day, the interviews were carried out similarly to the observations, and they were written in a computer environment. Student diaries were cleaned weekly and recorded on the computer. After the written documents were completed, the raw data were transferred to the NVivo 11 Pro program along with the researcher's notes. The data were analyzed through this program. First of all, the raw data were read repeatedly and codes were created. The codes were transferred to the program and coding was carried out. After the coding was completed, the relationships between the codes were tried to be determined and similar codes were combined under common categories. In the next step, similar categories were combined under common themes. The formula was used to calculate the percentage of agreement between analyzes.

$$
\text { Percent of agreement }=\frac{\text { Amount of agreement }}{\text { Amount of agreement }+ \text { Amount of disagreement }} \times 100
$$

It can be said that reliability is achieved if the compliance percentages are $70 \%$ or more (Miles \& Huberman, 1994).

\section{Findings}

Content analysis results of students' observation data are given in Table 1.

Table 1.

Content Analysis Results of Observation Data

\begin{tabular}{llll}
\hline Theme & Code & Central & Rural \\
\cline { 3 - 4 } & & $\mathbf{f}$ & $\mathbf{f}$ \\
\hline Motivation & interest & 30 & 29 \\
& excitement & 25 & 27 \\
& desire & 32 & 30 \\
\hline Learning Process & entertainment & 32 & 29 \\
& knowledge sharing & 23 & 21 \\
& participation & 26 & 28 \\
& lesson follow up & 25 & 24 \\
& long attention span & 18 & 18 \\
\hline Social Skills & expressing thought & 16 & 14 \\
& listen & 25 & 26 \\
& helping each other & 10 & 13 \\
\hline Negative Behaviors & competition & 2 & 4 \\
& ambition & 1 & 1
\end{tabular}




\begin{tabular}{lll} 
lose & 1 & 2 \\
noise & 4 & 5 \\
\hline
\end{tabular}

According to the analysis results of the observation data given in Table 1, it was determined that the frequencies in the motivation theme are 30 for interest, 25 for excitement and 32 for desire in the lesson in the central region, and 29 for interest in the lesson, 27 for excitement and 30 for desire in the lesson in rural area. In the learning process theme, the frequencies were found to be 32 for entertainment, 23 for knowledge sharing, 26 for participation, 25 for follow-up, and 18 for long attention span in the center, and 29 for entertainment, 21 for knowledge sharing, 28 for participation, 24 for follow-up and 18 long attention span in the rural area. It was found that frequencies in the theme of social skills 16 for expressing thoughts, 25 for listening and 10 for helping each other in the center, and 14 for expressing thoughts, 26 for listening, and 13 for helping each other by speaking in rural area. In the theme of negative behaviors, the frequencies were found to be 2 for competition, 1 for ambition, 1 for losing and 4 for noise in the center, and 4 for competition, 1 for ambition, 2 for losing, and 5 for noise in rural area. Examples from the observation notes are given below:

R5-EG1: ... They read the information on the cards they received with their group mate and discuss among themselves which box they should put them in. He answers questions asked by his friend. She's trying to explain concepts to her. ...

C5-EG3: ... She is trying to tell his bandmates something. Meanwhile, he starts speaking by asking permission from his friends. ...

C5-EG-1: ... He is arguing with his bandmates because of the mistakes they made. He has trouble controlling his movements. He stands up and sits down. He taunts his friends in the other group....

The results of the content analysis of the data obtained from the diaries prepared by the students are given in Table 2.

Table 1.

Content Analysis Results of the Data of Students' Diaries

\begin{tabular}{|c|c|c|c|}
\hline \multirow[t]{2}{*}{ Theme } & \multirow[t]{2}{*}{ Code } & Central & Rural \\
\hline & & $f$ & $f$ \\
\hline $\begin{array}{l}\text { Average of Learned Concepts Per } \\
\text { Diary }\end{array}$ & concept & 3,2 & 2,7 \\
\hline \multirow[t]{10}{*}{ Feelings, Thoughts and Attitudes } & entertainment & 35 & 26 \\
\hline & desire & 27 & 21 \\
\hline & interest in & 30 & 32 \\
\hline & being happy & 17 & 14 \\
\hline & like the lesson & 20 & 17 \\
\hline & not feeling anxiety & 25 & 29 \\
\hline & excited & 18 & 10 \\
\hline & be curious & 11 & 11 \\
\hline & like school & 13 & 17 \\
\hline & like the teacher & 24 & 20 \\
\hline \multirow{4}{*}{$\begin{array}{l}\text { Behaviors } \\
\text { Lesson }\end{array}$} & togetherness with friends & 19 & 18 \\
\hline & make decisions together & 18 & 15 \\
\hline & share information/thought & 24 & 29 \\
\hline & be tolerant & 33 & 27 \\
\hline \multirow{2}{*}{$\begin{array}{l}\text { Good and Bad Aspects During The } \\
\text { Lesson }\end{array}$} & understand & 28 & 21 \\
\hline & memorization & 19 & 13 \\
\hline
\end{tabular}


YILDIZ \& şiMŞEK - Çukurova Üniversitesi Eğitim Fakültesi Dergisi, 50(2), 2021, 1367-1396

\begin{tabular}{llll} 
& comprehension & 17 & 14 \\
& do right & 17 & 21 \\
& win & 7 & 9 \\
& self-confidence & 16 & 11 \\
& ambition to win & 9 & 2 \\
& disagreement & 6 & - \\
\hline Suggestions for the Next Lesson & get angry & 4 & 34 \\
& continue in the same way & 4 & 2 \\
\hline
\end{tabular}

As can be seen from the results of the analysis given in Table 2, the concepts explained by the students in their diaries were examined and the number of concepts explained in the diaries was divided by the number of diaries and the number of concepts per diary was determined. Accordingly, the number of concepts that students learned per diary was calculated as 3.2 for the center and 2.7 for the rural area. In the theme of feelings, thoughts, and attitudes, it was determined that the frequencies are 35 for entertainment, 27 for desire to learn, 30 for interest in the lesson and learning, 17 for being happy, 20 for liking the lesson, 25 for not feeling anxiety, 18 for being excited, 11 for being curious, 13 for liking school and 26 for liking the teacher in the center, and 26 for entertainment, 21 for desire to learn, 32 for interest in the lesson and learning, 14 for being happy, 17 for liking the lesson, 29 for not feeling anxiety, 10 for being excited, 11 for being curious, 17 for liking the school and 20 for liking the teacher in the rural area. In the theme of behaviors displayed during the lesson it was found that the frequencies are 19 for togetherness with friends, 18 for decision and practice together, 24 for sharing information/thoughts, and 33 for tolerant behavior in the center, and 18 for togetherness with friends, 15 for decision and practice together, 29 information/thought sharing and 27 for tolerant behavior in rural area. In the theme of good and bad aspects during the lesson it was determined that the frequencies are 28 for understanding, 19 for memorization, 17 for comprehension, 17 for doing right, 7 for winning, 16 for self-confidence, 6 for ambition to win, 4 for disagreement and 4 for getting angry in the center and 28 for understanding, 13 for memorization, 14 for comprehension, 21 for doing right, 9 for winning, 11 for self-confidence, 9 for ambition to win and 2 for disagreement in rural area. In the theme of suggestions for the next lesson, it was determined that the frequencies are 32 for the games to continue in the same way, and 4 for change of group in the center, and 34 for the games to continue in the same way, and 2 for change of group in the rural area. Examples from the students' diaries are given below:

R5-EG2: ... Making chocolate was fun and delicious. I have a lot of fun at games and I'm doing it right. I am very happy that we won. ...

C5-EG1: ... You know, we had trouble with $X$ in the early days. We lost games because of him. I was very angry with him and we were always fighting. I told you I'll treat him better, maybe it will be better then. But now it's all over. He learns very well when $X$ asks for it. You know, I almost made a mistake today and $X$ warned me. We didn't get along at first, but now he's one of my best friends. ...

C5-EG3: ... I like the science lesson, school, and our dear teacher X more. ...

R5-EG1: ... I love this lesson because we spend this unit playing games. I think that in the next lessons, we will both have fun and learn. ...

The results of the content analysis of the data obtained from the interviews conducted to determine the students' views on the method are given in Table 3. 
Table 3.

Analysis Results of Students' Views on the Method

\begin{tabular}{|c|c|c|c|}
\hline \multirow[t]{2}{*}{ Theme } & \multirow[t]{2}{*}{ Code } & \multirow{2}{*}{$\begin{array}{l}\text { Central } \\
\mathbf{f}^{*}\end{array}$} & \multirow{2}{*}{$\begin{array}{l}\text { Rural } \\
f^{*}\end{array}$} \\
\hline & & & \\
\hline \multirow[t]{7}{*}{$\begin{array}{l}\text { The Effect of the Method on } \\
\text { Learning }\end{array}$} & $\begin{array}{l}\text { sufficient to provide } \\
\text { information. }\end{array}$ & 3 & 3 \\
\hline & learning with fun & 2 & 3 \\
\hline & $\begin{array}{l}\text { the subject of the teachers do } \\
\text { not need to tell }\end{array}$ & 3 & 1 \\
\hline & effective learning & 1 & 2 \\
\hline & easier to understand & 1 & 1 \\
\hline & memorable & 1 & 1 \\
\hline & cognitive development & 1 & - \\
\hline \multirow[t]{6}{*}{ Effect on Social Skills } & friendship relations & 2 & 3 \\
\hline & working together & 2 & 2 \\
\hline & respect for different ideas & 2 & 1 \\
\hline & task sharing & 1 & 1 \\
\hline & cooperation & - & 2 \\
\hline & group awareness & 1 & 1 \\
\hline \multirow{3}{*}{$\begin{array}{l}\text { The Effect of Attitude Towards } \\
\text { the Lesson }\end{array}$} & like the lesson & 2 & 3 \\
\hline & not feeling anxiety & 1 & 3 \\
\hline & desire to learn & 1 & 2 \\
\hline \multirow[t]{2}{*}{ Effect on Personal Development } & self-confidence & - & 2 \\
\hline & individual study & 1 & 1 \\
\hline Negative Aspects of the Method & not have negative aspects & 3 & 3 \\
\hline \multirow{4}{*}{$\begin{array}{l}\text { Conditions to be Considered } \\
\text { When the Method is Reapplied }\end{array}$} & do daily repetitions & 2 & 1 \\
\hline & get groupmates' opinions & 1 & - \\
\hline & give importance to friendships & - & 1 \\
\hline & be kind to friends & 1 & - \\
\hline
\end{tabular}

Students expressed more than one opinion.

Seen on the Table 3, in the theme of the effect of the method on learning, it was determined that the frequencies are 3 for the sufficient to provide information of the EG method 2 for learning by having fun, 3 for not needing the teacher to explain the subject, 1 for effective learning, 1 for easier understanding, 1 memorable information and 1 for cognitive development in the center and 3 for the sufficient to provide information, 3 for learning by having fun, 1 for not needing the teacher to explain the subject, 2 for effective learning, 1 for easier understanding and 1 memorable information in rural area. It was determined that these are because the method facilitates learning, frequent repetition of concepts, organizing knowledge in different ways, and transforming knowledge. In the theme of the 
YILDIZ \& ŞIMŞEK - Çukurova Üniversitesi Eğitim Fakültesi Dergisi, 50(2), 2021, 1367-1396

effect on social skills, it was found that the frequencies are 2 for friendship relations, 2 for working together, 2 for respecting different ideas, 1 for task sharing and 1 for group awareness in the center, and 3 for friendship relations, 2 for working together, 1 respecting different ideas, 1 for task sharing, 2 for cooperation and 1 for group awareness in rural area. It was determined that these are caused by the intensity of communication between groupmates and the situations of making and implementing decisions together. In the theme of the effect of attitude towards the lesson, it was determined that the frequencies are 2 for liking the lesson, 1 for not feeling anxiety in the lesson and 1 for the desire to learn in the center and 3 for liking the lesson, 3 for not feeling anxiety in the lesson, and 2 for the desire to learn in rural area. It was determined that these are due to excitement, the method being fun, enjoyable, and intriguing. In the theme of the effect on personal development, it was determined that the frequencies are 2 for self-confidence in the center and 1 for self-confidence and 1 for individual study habit in rural area. It was determined that the reason for this is the sense of achievement. It was determined that all of the students thought that the method do not have any negative aspects. When the method was re-applied, it was determined that the frequencies are 2 for doing daily repetition, 1 for asking the opinions of groupmates and 1 for being tolerant of friends in the center and 1 for doing daily repetition, and 1 for giving importance to friendship relations in rural area. Examples of the answers given by the students are given below:

R5-EG1: ... Teacher, for example, I'm afraid that I will fail the classes, but I have no such feeling in science. It feels like science is my life. It was like that in science in the past, but after playing the games our teacher prepared for us, as I said, it was like I had a science life. ...

C5-EG3: ... My desire to learn has increased a lot. For example, now I want to learn a lot. For example, let's say there is a subject that I want to learn more about. I'm studying more science. I work even though I don't have homework. ...

R5-EG2: ... I always asked my mother: What was that? What was this? What was that? Do you know? Now I can work alone. I always remember what we did in the game. While I work, I also work using them. ...

The results of the content analysis of the data obtained from the interviews conducted to determine the students' views on the solution of the learning problems experienced by the EG method are given in Table 4.

Table 4.

Analysis Results of Students' Opinions on the Solution of the Learning Problem They Experienced with the EG Method

\begin{tabular}{|c|c|c|c|}
\hline \multirow[t]{2}{*}{ Theme } & \multirow[t]{2}{*}{ Code } & \multirow{2}{*}{$\begin{array}{l}\text { Central } \\
\mathbf{f}^{*}\end{array}$} & \multirow{2}{*}{$\begin{array}{l}\text { Rural } \\
f^{*}\end{array}$} \\
\hline & & & \\
\hline $\begin{array}{l}\text { Application of Subjects } \\
\text { with Learning Problems in } \\
\text { Teaching }\end{array}$ & willing to implement & 3 & 3 \\
\hline \multirow[t]{2}{*}{ Effects on Learning } & $\begin{array}{l}\text { effective in increasing } \\
\text { achievement }\end{array}$ & 3 & 3 \\
\hline & $\begin{array}{l}\text { effective in increasing } \\
\text { persistence }\end{array}$ & 3 & 3 \\
\hline \multirow[t]{2}{*}{$\begin{array}{l}\text { Effects on Affective } \\
\text { Factors }\end{array}$} & $\begin{array}{l}\text { effective in increasing } \\
\text { motivation }\end{array}$ & 3 & 3 \\
\hline & $\begin{array}{l}\text { effective in reducing } \\
\text { anxiety }\end{array}$ & 3 & 3 \\
\hline Reasons for Effects on & interesting & 2 & 3 \\
\hline Solving Learning Problems & funny & 2 & 3 \\
\hline
\end{tabular}




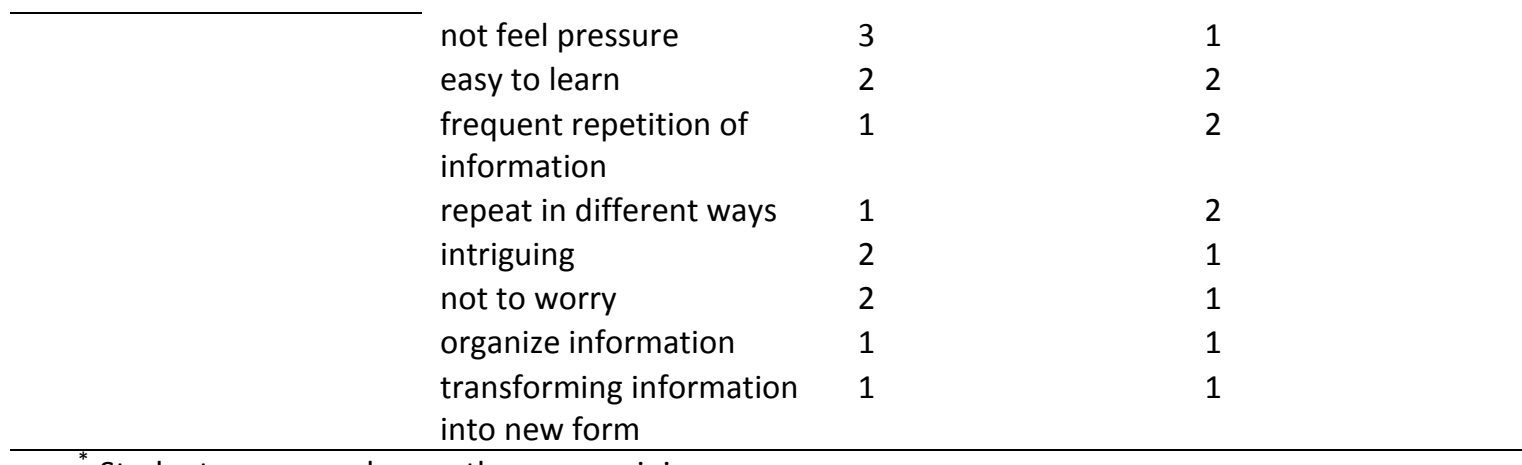

Students expressed more than one opinion.

As it presented on the Table 4, all of the students want the EG method to be used in the teaching of subjects with learning problems. In the theme of effects on learning, it was determined that the frequencies are 3 for effectiveness in increasing achievement and 3 for effectiveness in increasing persistence in the center, and 3 for effectiveness in increasing achievement and 3 for effectiveness in increasing permanence in rural area. In the theme of effects on affective factors, it was determined that the frequencies are 3 for effectiveness in increasing motivation and 3 for effectiveness in reducing anxiety in the center and 3 for effectiveness in increasing motivation, and 3 for effectiveness in reducing anxiety in rural area. In the theme of reasons for effects on solving learning problems, the frequencies are 2 for the method being interesting, 2 for being fun, 2 for the intriguing, 3 for not feeling pressure, 2 for easy learning, 1 for repeating the information frequently, 1 for repeating in different ways, 2 for not worrying, 1 for organizing information, 1 for transforming information into a new form in the center and 3 for the method being interesting, 3 for being fun, 1 for the intriguing, 1 for not feeling pressure, 2 for easy learning, 2 for repeating information frequently, 2 for repeating information in different ways, 1 for not worrying, organizing information and 1 for transforming information into a new form in rural area. Examples of the answers given by the students are given below:

R5-EG2: ... I think my success has increased even more. Because when I love and have fun, I do my lessons more carefully. When I go home, I want to study more in my studies. I am learning better. ...

R5-EG3: ... Games are a lot of fun. I was never bored in classes. I always wanted to learn more. I knew that the more I learned, the more successful I would be at the games. For him, I think it worked for the issue that I had a problem with.

C5-EG1: ... For example, when a question was asked, it would be very difficult for me if the teacher had told it. I'm thinking, I'm having a hard time, I think so. I don't even think of it. But I always remember what we did in the game. When I have a question, I can respond quickly.

\section{Discussion \& Conclusion}

In this research, which was conducted to determine the perceptions of the students about the EG method applied in the teaching of the subject of "Matter and Change" which they have learning problems, student behaviors were observed throughout the process, the students wrote a diary, the students were interviewed, and the data obtained in the process were analyzed by content analysis method. Obtained results are presented below.

The first consideration is about the students' perceptions of EG method. In the light of the results, it was concluded that the students found the EG method sufficient in terms of providing information, they learned more effectively and easily with this method, the games made them understand better, they realized meaningful learning, the method increased the achievement due to the frequent repetition of information, organizing and transforming information in various ways to win the game. The results 
obtained in different studies conducted at the fifth-grade level in the literature support the results that the method obtained from this study is effective on success (Anderson, 2008; Aymen-Peker, 2018; Çelik, 2017; Dowling, 2012; Koka, 2018). The result of the study by Neimeyer (2006) that teaching with games does not affect achievement contradicts the result of this research. It can be said that the differences in the methods adopted in the research, data collection, and analysis methods are effective in the differentiation of the results of the two studies. In this research, qualitative design was adopted, data were collected by diary, observation, interview, analyzed with content analysis, and in the research conducted by Neimeyer (2006), the quantitative design was adopted, data were collected with achievement test and analyzed with significance tests. Therefore, while the result that the EG method is effective in learning and improving academic achievement depends on the perceptions of the students in this study, differentiation may have been observed in the results of Neimeyer (2006) as it depends on the analysis of significance.

The second consideration is related to the effectiveness of EG method. The results of the present study indicated that the students learned the concepts effectively with the EG method without the need for their teachers to explain the subject, and the rate of concept learning was high. Similarly, studies conducted at the fifth grade (Aymen-Peker, 2018; Dowling, 2012), seventh-grade (Boyce, 2016), and eighth-grade levels (Harvey, 2018) indicated that educational games are effective in concept learning.

Regarding the impact of EG method on motivation as the third consideration, the results showed that the EG method increased the motivation to learn because the games are fun, interesting, enjoyable, and intriguing, they feel happy, it provides learning by having fun for the students, and the students are interested and willing to learn and the lesson during the games. The results obtained from this research are compatible with the results obtained in the studies conducted at the seventh-grade level (Say \& Bağ, 2017; Toprac, 2008) and the eighth-grade level (Bressler, 2014; Nunes, Soares \& Catarino, 2018) in the literature, that it is effective in improving learning motivation. A study conducted by Atwood-Blaine (2015), contradicts the result of the research that teaching with games is not effective on the motivation of seventh-grade students. It can be said that this situation arises from the differences between the samples of the researches, the game types, and the application times. Considering the developmental characteristics of the fifth-grade students, it can be said that they show more interest in games and since the seventh-grade students are in the transition phase from the concrete operational stage to the abstract operational stage, they do not show as much interest in games as the fifth-grade students.

The forth consideration emerging from the content analysis was that the EG method made the students like the subject, the lesson, the teacher, and the school more. The results obtained from this research are compatible with the result of the studies conducted at the secondary school level in the literature that teaching with games is effective in improving students' attitudes (Çelik, 2017; Eltem, 2018; Gürpınar, 2017; Nunes, Soares \& Catarino, 2018; Yeşilkaya, 2013; Yıldız, Şimşek \& Agdas, 2018). Similarly, Zheng and Hiller (2012), working with fifth-grade students, concluded that teaching with games was not effective on students' attitudes. The difference in the results of the two studies working in similar sample groups may be due to the different types of games used.

Taking the relationship between EG method and anxiety, it was found that the EG method reduced learning anxiety because students do not feel the pressure and anxiety that are normally in the classroom environment during the games. The results obtained from this study are in line with the results of the research that stated that the educational game method applied at the sixth-grade level is effective in reducing learning anxiety (Yıldız, Şimşek, \& Aras, 2017).

As the last consideration obtained from the results, it was inferred that the EG method improved friendship relations, task sharing, working and learning together, expressing thoughts by taking the floor, listening to teachers and friends, respecting each other's thoughts, information sharing, cooperation, group awareness, self-confidence, decision making, and implementation skills. It was determined that students have negative behaviors such as ambition to win, disagreement, and competition, but students are aware of this situation and make an effort to correct it. Similarly, studies 
YILDIZ \& ŞIMŞEK - Çukurova Üniversitesi Eğitim Fakültesi Dergisi, 50(2), 2021, 1367-1396

at the secondary school level have concluded that the EG method improves students' social skills (Yıldız, Şimşek, \& Aras, 2017) and their ability to work together (Bressler, 2014). Contrary to the results of this research, Fanetti (2011) working at the undergraduate level has concluded that the EG method is not effective in the development of social skills. The contradiction between the results of this research using real environment games and the results of the research using video games may be due to the difference in research samples and game types. It can be said that games played in a real environment enable students to interact and communicate more with each other than video games, and therefore they are more effective in improving students' social skills.

This research, which was conducted at the fifth-grade level by taking data from six students from central and rural areas with daily observations and interviews, was completed in 26 lesson hours in the unit of "Matter and Change". Since it was determined that students' perceptions of the EG method are positive, that teaching with games is effective on success, motivation, attitude, anxiety, and social skills, and that it is a solution to learning problems, it may be beneficial for educators to use this method in teaching different subjects. The EG method can be applied at different grade levels. It can be applied in groups of students with low levels of achievement, motivation, attitude, or social skills. It may be beneficial to apply it in classrooms where students with high levels of anxiety are present. 


\section{Türkçe Sürümü}

\section{Giriş}

Oyun aktiviteleri genel olarak yetişkinler tarafından boş zaman eğlenceleri olarak değerlendirilmektedir. Oysa oyun her yaştan bireyin ilgisini çeken, merak uyandıran, severek ve isteyerek katıldıkları ve çeşitli açılardan gelişimlerini sağlayan eğlenceli aktivitelerdir. Bu nedenle oyunların her yaştan birey için bir ihtiyaç olduğu söylenebilir. Benzer şekilde Demir ve Kurt (2015) günümüzde oyunların hem çocuklar hem de yetişkinler için bir ihtiyaç olduğunu ifade etmiştir.

Türk Dil Kurumunun "Yetenek ve zeka geliştirici, belli kuralları olan, iyi vakit geçirmeye yarayan eğlence" olarak tanımladığı oyunlar çok farklı alanlarda çalışılan ve bireyin çok yönlü gelişmesini sağlayan bir araç olduğundan birçok araştırmacı tarafından da farklı şekillerde tanımlanmıştır. Dönmez (1992)'e göre oyun; amaçlı veya amaçsız, kurallı veya kuralsız ne şekilde gerçekleştirilirse gerçekleştirilsin her koşulda bireyin isteyerek ve severek dahil olduğu fiziksel, duyuşsal ve sosyal gelişimini sağlayan, öğrenmesinde etkili bir araç olan gerçek hayatın bir parçasıdır. Oyun, kimi araştırmacılara göre dış tehdit ve stres unsurları olmadığında ortaya çıkan doğal bir etkinlik (Aamondt \& Wank, 2011), kimi araştırmacılara göre ise öğrenmeye yardımcı olan pedagojik bir araçtır (Fleer, 2014). Oyunlar; çocukların fazla enerjilerini attıkları, dinlendiren, sosyal rolleri öğreten, yetişkinliğe hazırlayan, atalarından aktarılan davranışları yeniden yaşatan, gerçek yaşamı anlamalarını sağlayan, yeni beceriler kazandıran ve bunları pekiştiren, fiziksel, bilişsel, duyuşsal ve sosyal alanlarda geliştiren, problem çözme becerileri kazandıran ve birçok araştırmacı tarafından öğrenme sanatı (Poyraz, 2003) olarak nitelendirilen bir araçtır. Oyunlar araştırmacılar tarafından farklı şekillerde sınıflandırılmaktadır (Hazar, 2006). Akandere (2012) oyunları çocuk oyunları ve eğitsel oyunlar olmak üzere iki başlık altında incelemektedir.

Eğitsel oyun (EO) yöntemi, eğitimsel amaçların gerçekleştirilmesi amacıyla gerçek bir eğlence ortamında öğrencilerin etkileşimlerini artırarak daha etkin öğrenmeler sağlayan eğitsel oyunların öğrenme ortamlarında kullanılmasını içeren aktif öğrenme yöntemlerinden biridir (MacKenzie, 2014; Michael \& Chen, 2006). Öğrenme ortamı eğlenceli olduğunda daha etkin öğrenmeler gerçekleştiği görülmektedir ve oyunlar hayal dünyası, merak, macera, rol yapma, strateji, spor ve meydan okuma gibi unsurları bir araya getirerek eğlence düzeyini artırmaktadır (Gros, 2007; Malone, Lepper, Snow \& Farr, 1987; Stewart, 2013). Görselleştirme, keşfetme ve problem çözme gibi merkezi bileşenlere sahip eğitsel oyunlar özellikle fen bilimlerinde, deney ve yaratıcılık yoluyla öğrenmeyi artırmaktadır (Habraken, 2004; Rieber, Luke \& Smith, 1998; Squire \& Jenkins, 2003). Doğal bir öğrenme aracı olan oyun çocukların kendi deneyimleri aracılığıyla öğrenmesini sağlar (Özgür, 2000).

EO yöntemi öğrencilerin öğrenme motivayonunu, derse katılım oranını artıran, dersi, öğretmeni, okulu sevdiren, grup içinde söz alma, dinleme, düşüncelerini aktarma, farklı düşüncelere saygı gösterme, yardımlaşma gibi sosyal becerileri geliştiren, stress ve kaygıyı azaltan etkili bir yöntemdir (Akandere, 2012; Bilen, 2002; Pehlivan, 2014). Ancak bunun için oyunlar hazırlanırken oyunun amacı, oyun için yapılması gerekenler, oyunun oynanışı, değerlendirilmesi ve geliştirilmesi ile ilgili ayrıntılar önceden planlanmalıdır (Akandere, 2012; Pehlivan, 2014). Oyunlar iyi bir şekilde planlanmadığında yöntem birçok sınırlılıkla karşımıza çıkmaktadır. Bu tür durumların yaşanmaması için rekabetin olumlu düzeyde tutulması, öğrenci seviyesine uygun olması, öğrencilerin başaramayacağı düzeyde zorluk içermemesi, tüm öğrencilerin sürece katılması, oyunun öğrencilerin alamayacağı şekilde zor ve karışık olmaması gerekmektedir (Demirel, 1999; Pehlivan, 2014).

Alanyazında yapılan araştırmalar incelendiğinde ortaokul düzeyindeki EO yöntemine yönelik araştırmaların başarı değişkeni üzerine odaklandığı ve yöntemin başarıyı artırmada ve kavram öğrenmede etkili olduğu sonucuna ulaşıldığı görülmektedir (Anderson, 2008; Aymen-Peker, 2018; Boyce, 2016; Dowling, 2012; Eltem, 2018; Espinoza Morales, 2017; Folta, 2010; Gençer, 2016; Gürpınar, 2017; Harvey, 2018; Huang, 2016; Koka, 2018; Yıldız, Şimşek \& Ağdaş, 2018; Yıldız, Şimşek, \& Aras, 2016). 
Eltem (2018), Harvey (2018) ve Peng (2009) öğrencilerin yönteme yönelik tepkilerini ve görüşlerini incelemiş ve genellikle EO yöntemine yönelik olumlu tutum ve görüşlerin olduğu sonucuna ulaşmıştır. Boyce (2016) ise öğrenme güçlüğü olan yedinci sınıf öğrencileriyle çalışmış ve yöntemin kavram gelişiminde etkili olduğu ve öğrencilerin olumlu davranışlar sergilediği sonucuna ulaşmıştır. Şentürk, (2020) yaptığı araştırmanın nitel kısmında gerçekleştirilen görüşmeler ve öğrenci günlüklerinden elde edilen verilerin analizi neticesinde EO yönteminin dördüncü sınıf öğrencilerinin bilişsel, duyuşsal ve sosyal yönlerden gelişimini desteklediği sonucuna ulaşmıştır. İncelenen araştırmalardan görüldüğü üzere öğrencilerin yönteme yönelik tepkilerinin ve görüşlerinin incelendiği araştırmalar geri planda kalmaktadır. Öğrencilerin gelişimlerine etkisinin incelenmesi kadar bu gelişimlerin arka planında yer alan nedenlerin ve gelişimlerin nasıl gerçekleştiğinin incelenmesi de önem arz etmektedir. Bu nedenle bu araştırmada öğrencilerin EO yöntemine yönelik algıları ve nedenleri incelenmiştir.

Alanyazında yapılan araştırmalar incelendiğinde beşinci sınıf öğrencilerinin "Madde ve Değişim" ünitesinde öğrenme zorluğu, motivasyon düşüklüğü, öğrenme kaygısının yükselmesi gibi problemler yaşadığı (Yıldız, 2019) ve ISI, sıcaklık, buharlaşma vb. birçok kavramda kavram yanılgısı olduğu görülmektedir (Buluş Kıııkaya \& Güllü, 2008). Bu araştırma öğrencilerin, öğrenme problemleri yaşandığı tespit edilen "Madde ve Değişim" konusunun öğretiminde uygulanan EO yöntemine yönelik algılarını belirlemek amacıyla yapılmıştır. Bu amaca bağlı olarak araştırmanın problem cümlesi: "Öğrencilerin öğrenme problemleri yaşandığı belirlenen "Madde ve Değişim" ünitesinde uygulanan EO yöntemine yönelik algıları nasııdır?" şeklinde belirlenmiştir.

Yöntem

\section{Araştırma Deseni}

Araştırmada durum çalışması yöntemi kullanılmışır. Durum çalışması bir veya birden fazla durumun, grubun, olayın veya birbiriyle bağlantılı sistemlerin ayrıntılı olarak çalışıldığı yöntemdir (Glesne, 2011; McMillan, 2000). Durum çalışmasında genelde kontrol altına alınamayan gerçek yaşam durumlarına ilişkin derinlemesine çalışıı (Yin, 2003). Bu araştırmada, yöntemin uygulanışı sırasında davranışlarına müdahalede bulunulmadan öğrencilerin yönteme karşı tepkilerinin incelenmesi, yönteme yönelik görüşleri ve bunların arkasındaki nedenler araştıııldı̆ından en uygun yöntem durum çalışmasıdır. Bu yöntemde birden fazla veri toplama aracının kullanılmasının yarar sağlayacağı (Gillham, 2000) belirtildiğinden veriler gözlem, günlük ve görüşme aracılı̆̆ıyla toplanmıştır. Araştırma sonuçlarının geçerliğini artırmak amacıyla; farklı veri kaynakları kullanılmıs, alan çalışmaları yedi hafta gibi geniş bir zaman diliminde gerçekleştirilmiş, bir alan uzmanı çalışma hakkında bilgilendirilerek düzenli dönütler alınmış, sürece ikinci bir araştırmacı dahil edilmiş, bulgular doğrudan alıntılarla desteklenmiş, ayrışan örneklemler belirlenerek bunlar üzerinde çalışııı̧̧ ve mümkün olduğu kadar herhangi bir beklenti içerisine girilmemeye ve önyargılı davranılmamaya çalışılmıştır.

\section{Katılımcilar}

Araştırma 2017-2018 akademik yılında Erzurum ili merkez ve kırsal bölgelerde öğrenim gören altı beşinci sınıf öğrencisi ile gerçekleştirilmiştir. Öğrencilerin belirlenmesinde maksimum çeşit örnekleme kullanılmıştır. Bu örneklemenin temel amacı, belirlenen amaç doğrultusunda farklı durumlar arasındaki birleşen veya ayrışan yönlerin ortaya çıkarılmasıyla problem durumunun daha geniş bir çerçevede irdelenmesini sağlamaktır (Johnson \& Christensen, 2014). Öğrencilerin yönteme yönelik tepkilerinde ve görüşlerinde etkili olabileceği düşünülen öğrencinin öğrenim gördüğü bölge ve başarı durumu dikkate alınmıştır. Buna göre her iki bölgede de bir başarılı, bir orta düzey başarılı ve bir düşük başarı düzeyine sahip öğrenci belirlenmiştir. Öğrenciler belirlenirken yöntemin başlangıcında uygulanan öntest puanları dikkate alınmıştır. Seçilen öğrencilerde gönüllülük esası aranmış ve katılım göstermek istemeyen öğrencilerin yerine benzer özelliklerde yeni öğrenciler seçilmiştir. Uygulamanın başlangııında öğrencilerin araştırmaya katııması için velilerinden elde edilen verilerin yalnızca bilimsel amaçla kullanılması ve öğrencinin kimliğinin gizli tutulması şartıyla izin alınmışır. Merkezdeki öğrenciler M5EO1, M5-EO2, M5-EO3 şeklinde ve kırsaldaki öğrenciler K5-EO1, K5-EO2, K5-EO3 şeklinde kodlanmışır. 


\section{Veri Toplama Araçları}

\section{Yarı-yapılandırılmış görüşme}

Öğrencilerin uygulanan eğitsel oyun yöntemine ve bu yöntemin öğrenme problemlerini gidermedeki etkisine yönelik görüşlerini belirlemek amacıyla iki aşamalı yarı-yapılandırılmış görüşme yapılmıştır. Görüşmenin ilk aşaması sekiz sorudan oluşmaktadır. Bu aşamadaki sorular öğrencilerin yöntem ile ne derece etkili öğrendikleri, yöntemin olumlu ve olumsuz yönleri, eğlence, bilgi sağlama, becerileri geliştirme, bireysel ve grupla çalışma becerisi üzerindeki etkileri hakkındaki düşüncelerini belirlemeye yöneliktir. Görüşmenin ikinci aşaması ise beş sorudan oluşmaktadır. Bu aşamadaki sorular yöntemin öğrencilerin öğrenme problemi yaşadığı konularda uygulanmasının başarı, motivasyon, kaygı ve bilgilerinin kalıcılığı üzerindeki etkileri hakkındaki düşüncelerini belirlemeye yöneliktir.

Hazırlanan tüm görüşme soruları uzman değerlendirme formları ile birlikte üç fen bilgisi eğitimi alan uzmanına gönderilmiştir. Uzmanların görüşleri dikkate alınarak düzenlenen sorular ilk olarak seçilen iki öğrenciye uygulanarak pilot çalışmaları yapılmıştır. Pilot çalışmalar sırasında görüşme ortamının rahatıl̆ğı, öğrencilerin soruları cevaplamadaki rahatıkları, öğrencilerin soruları anlama düzeyleri ve cevapları derinleştirmek adına ne tür soruların sorulabileceği gibi durumlar incelenerek asıl görüşmeler için gerekli düzenlemeler yapılmıştır. Pilot çalışmalar tamamlandıktan sonra elde edilen veriler hızlıca analiz edilerek soruların sorulma amaçlarını tam olarak karşılayıp karşılamadığı incelenmiştir.

Görüşmeler merkezdeki okulda okulun rehberlik servisi tarafından kullanılan bir odada ve kırsal kesimdeki okulda ise öğretmenler odasına ek olarak yapılan bir odada gerçekleştirilmiştir. Öğrenciler görüşmeye alındığında öncelikle ortama alışmaları sağlanmaya çalışılmıştır. Görüşmeler sırasında ortamda yalnızca araştırmacı ve öğrenci bulunmuştur. Öğrencilerin verecekleri cevapların onları değerlendirmek amacıyla kullanılmayacağı, herhangi bir şekilde notlarını etkilemeyeceği, öğretmenlerinin verdikleri cevaplardan kesinlikle haberi olmayacağı, verecekleri cevapların öğretmenlerini değerlendirmeye yönelik olmadığı ve yalnızca onların yönteme yönelik görüşlerini belirlemek amacıyla sorular sorulacağı açıklanmışır. Öğrencilere görüşmeler sırasında ses kayıt cihazının kullanılacağı belirtilerek, ses kayıtlarının araştırmacının konuşmaları yazılı hale dönüştürmesi amacıyla alındığı, kimseyle paylaşımayacağı, öğrencilerin gerçek kimliklerinin gizleneceği konusunda bilgilendirilmiştir. Görüşme soruları sırasıyla öğrencilere yöneltilmiş ve öğrencilerden gelen cevaplara göre ek sorular sorulmuştur. Ek sorular öğrencilerin verdikleri cevapları derinleştirmek ve cevaplar hakkında daha fazla bilgi toplamak amacıyla sorulmuştur. Aralıklı olarak öğrencilerin verdiği cevaplar tekrar edilerek teyitler alınmıştır. Her görüşmenin sonunda öğrencilere eklemek istedikleri bir şeyin olup olmadığı sorulmuştur. Görüşmeler ortalama 15-25 dakika arasında sürmüştür. Her öğrenci ile belirlenen iki farklı zamanda görüşme yapılarak veriler toplanmıştır. Görüşmenin yapıldığı günün sonunda kayıtlar yazılı hale getirilmiş ve görüşme ile ilgili araştırmacı notları yazııı forma kaydedilmiştir.

Görüşme verileri araştırmacı tarafından iki farklı zamanda analiz edilmiştir. Elde edilen verilerin ikinci bir araştırmacı tarafından analiz edilmesi sağlanmıştır. Birinci görüşmeler için araştırmacının farklı zamanlarda yaptığı analizler arasındaki uyum yüzdesi $\% 84$ ve iki araştırmacının yaptığı analizler arasındaki Kappa katsayısı 0,74 olarak hesaplanmışır. İkinci görüşmeler için araştırmacının farklı zamanlarda yaptığı analizler arasındaki uyum yüzdesi \%85 ve iki araştırmacının yaptığı analizler arasındaki uyum yüzdesi \%72 olarak hesaplanmıştır.

\section{Yapılandırılmamış gözlem}

Gözlemlerle ilgili süreç başlamadan önce alan uzmanlarından görüş alınmıştır. Uzmanların gözlemlerde gözlem formunun kullanılmasının verileri sınırlandıracağını, davranışlarda beklentiye gidilmesinin öğrencilerin farklı davranışlarını kaçırmaya neden olacağını belirtmeleri ve yapılandıııımamış gözlem yapılmasını önermeleri nedeniyle gözlemler yapılandııılmamış olarak gerçekleştirilmiştir.

Gözlemler uygulama başlamadan iki hafta önce uygulayıcı öğretmenlerin derslerinde haftalık ikişer saat olarak yapılmaya başlanmıştır. Gözlemlerin uygulamadan önce başlatılmasının nedenleri: 
- Öğrencilerin ve öğretmenlerin sınıfta olan bir yabancının varlığına alışmalarını sağlayarak davranışlarını doğallaştırmak,

- Derste yapılan kamera kayıtlarının normalleştirilmesi ve kayıtlar sebebiyle sergilenecek yapmacık davranışların önüne geçmek,

- Sınıf, öğretmen ve öğrencileri betimlemektir.

Illk iki haftalık gözlemde sınıflar, öğretmenler ve öğrenciler tasvir edilmiştir. Bu süreç araştırma verilerine dahil olmasa da araştırma verilerinin analizlerinde bütüncül bakış açısını sağlama ve ortamın sergilenen davranışlar üzerindeki etkisi açısından önem arz etmektedir. Bu tasvirlerde sınıfın fiziksel yapısı ayrıntılı olarak açıklanmış, öğretmenlerin ve öğrencilerin genel yapıları, aralarındaki iletişim detaylı bir şekilde gözlenmeye çalışılıı̧ıır.

Gözlemler araştırmacı ve sürece dahil olan ikinci bir araştırmacı tarafından eş zamanlı olarak yapıımışıı. Aynı zamanda dersler kamera ile kayıt altına alınmıştır. Her gözlemin başında araştırmacı kısaca kendini (duygu ve düşüncelerini, nasıl bir ruh haline sahip olduğunu) anlatmıştır. Araştırmacının gözlemlerin başlangıcında kendini anlatması verilerin analiz kısmında gözlemleri nasıl bir ruh haliyle yaptığı konusunda fikir vermiştir. Gözlemin gerçekleştirildiği günün sonunda iki araştırmacının gözlem notları ve kamera kayıtları incelenerek gözlem verileri kaydedilmiştir. Gözlemlerle ilgili araştırmacı notları da analizlerde yardımcı olması açısından gözlem verilerine eklenmiştir.

Gözlem verileri araştırmacı tarafından iki farklı zamanda analiz edilmiştir. Verilerin ikinci araştırmacı tarafından bağımsız olarak analiz edilmesi sağlanmıştır. Araştırmacının farklı zamanlarda yaptığı analizler arasındaki uyum yüzdesi \%77 ve iki araştırmacının yaptığı analizler arasındaki uyum yüzdesi \%71 olarak hesaplanmıştır.

\section{Öğrenci günlükleri}

Öğrencilerin haftalık iki adet (her iki ders saati için bir günlük) günlük yazmaları istenmiştir. Öğrencilerden günlüklerinde aşağıda verilen başıkları yazmaları istenmiştir:

- Derste neler yaptıklarınızı, dersi nasıl işlediğinizi özet şeklinde anlatın.

- Derste neler öğrendiğinizi herhangi bir kaynaktan yararlanmadan aklınızda kaldığı kadarıyla açıklayın.

- Ders süresince duygularınızın, düşüncelerinizin ve tutumlarınızın neler olduğunu nedenleri ile birlikte açıklayın.

- Ders süresince sergilediğiniz davranışları nedenleri ile birlikte anlatın.

- Ders süresince iyi ve kötü olduğunuz yönlerinizi anlatın.

- Sonraki dersler için önerilerinizi açıklayın.

Öğrenciler için günlük hazırlama yönergesi araştırmacı tarafından hazırlanmış yöntemler uygulanmaya başlamadan iki hafta önce öğrencilere verilerek yöntem uygulaması başlayana kadar günlük yazmaya alışmaları sağlanmaya çalışımışıı. Öğrenciler günlüklerini yazarken aşă̆ıda belirtilen hususlara dikkat etmiştir:

- Günlükler A4 boyutunda beyaz veya isteğe bağlı renkli kağıtlara yazılmalıdır.

- Günlüklerde içten, doğal ve günlük dil kullanılmalı ve günlüğe istenildiği şekilde hitap edilmelidir.

- Günlük istenilen şekilde renkli kalemler kullanılarak hazırlanabilir, resimler çizilebilir ve çıkarmalar yapıştırılabilir. Günlüklerini süslemede bireyler özgürdür.

- Günlük anlaşılır biçimde; Türkçe yazım ve imla kurallarına uygun yazılmalıdır.

- Günlük, fen bilimleri dersi için yazıımalı ve ders dışında kalan anlatımlardan kaçınılmalıdır.

- Günlük, hazırlama yönergesi takip edilmeli ve yönergede bahsedilen tüm başlıklar günlük içinde yer almalıdır.

- Başlıklar birbirinden kopuk bağlantısız şekilde ele alınmamalı bir bütün içinde verilmelidir. 
Uygulama başlamadan önceki iki haftalık günlükler detaylıca incelenerek dönütler hazırlanmış ve uygulayıcı öğretmenlerle paylaşılmıştır. Öğretmenler öğrencileriyle bu dönütleri paylaşarak öğrencilerinin istenilen formata uygun günlük yazmalarına yardımcı olmuştur. Tüm öğrencilerin günlük yazmaları istenmiş tüm günlükler araştırmacı tarafından okunmuş, ancak katılımcı olarak belirlenen öğrencilerin günlükleri analizler için değerlendirmeye alınmıştır.

Günlüklerden elde edilen veriler araştırmacı tarafından iki farklı zamanda analiz edilmiştir. İkinci bir uzmanın verileri analiz etmesi istenmiştir. Araştırmacının farklı zamanlarda yaptığı analizler arasındaki uyum yüzdesi \%82 ve iki araştırmacının yaptığı analizler arasındaki uyum yüzdesi \%76 olarak hesaplanmıştır.

\section{Verilerin Toplanması}

Araştırmacı tarafından hem merkez hem de kırsal bölgede EO yöntemini uygulayacak öğretmenler için Uygulayıcı Rehberi hazırlanmıştır. Bu rehber, EO yöntemiyle ilgili genel bilgiler, yöntemde kullanılan eğitsel oyunların tasarımı, kuralları ve oynanışı, konuyla ilgili etkinlikler, ödevler ve yöntemin konunun öğretiminde uygulanmasına yönelik detaylı uygulama planından oluşmaktadır. Rehber uygulamayı yapacak öğretmenlere bir ay öncesinde verilmiştir. Öğretmenler rehberi incelediklerinde araştırmacı tarafından iki defa seminer düzenlenmiş ve öğretmenlerin süreçte yapacakları eylemler ayrıntılı olarak açıklanmıştır. Ayrıca her hafta yapılacak olan eylemler öğretmenlere düzenli olarak hatırlatılmıştır. Araştırmacı sürece yalnızca gözlemci olarak katılmış ve sınıf içindeki tüm uygulamalar öğretmen tarafından gerçekleştirilmiştir. Konunun öğretimi için tasarlanan eğitsel oyunlar öğretmen tarafından uygulanmış, etkinlikler oyunlaştırılarak gerçekleştirilmiş ve ödevler belirlenen zamanlarda verilmiş ve değerlendirilmiştir. Uygulama bu şekilde 26 ders saatinde tamamlanmıştır. Süreç boyunca gözlem ve günlük verileri alınmış, süreç sonunda görüşmeler iki aşamada gerçekleştirilmiştir.

Araştırma Erzurum il Milli Eğitim Müdürlüğünün 06.10.2017 tarihli ve 36648235-605.01.E.16089927 nolu izni kapsamında gerçekleştirilmiştir. Araştırmanın gerçekleştirildiği okul müdürüne ve sınıfın fen bilimleri öğretmenine araştırma onay formu imzalatılmıştır. Atatürk Üniversitesi Sosyal ve Beşeri Bilimler Etik Kurulu'nun 26.10.2016 tarih ve 48553601-000-E.1600268066 sayılı belgesi, araştırmanın etik kurallara uygun olarak gerçekleştirildiğini göstermektedir.

\section{Verilerin Analizi}

Verilerin analizleri içerik analizi yöntemi ile gerçekleştirilmiştir. İçerik analizi, araştırmacıların insan davranışlarını onlarla iletişiminin analizi aracılığıyla dolaylı olarak incelemelerini sağlayan bir tekniktir. Her zaman olmasa da genellikle iletişimdeki yazılı dokümanlar olmak üzere, ses kayıtları, görüntü kayıtları veya resimler vb. herhangi bir kaynaktan elde edilen verilerin mesajlarının keşfedilmesi, anlamlı bir şekilde ortaya konması, derinlemesine incelenmesi açısından araştırmacılara olanak sağlayan nitel veri analizinde sıklıkla başvurulan bir tekniktir (Fraenkel, Wallen \& Hyun, 2011; Neuman, 2014). Verilerin içerik analizi ile analiz edilmesinde Şekil 1'de verilen işlem adımları takip edilmiştir. 
Verilerin yazılı formlarının oluşturulması

Tekrarlı okumaların yapılması

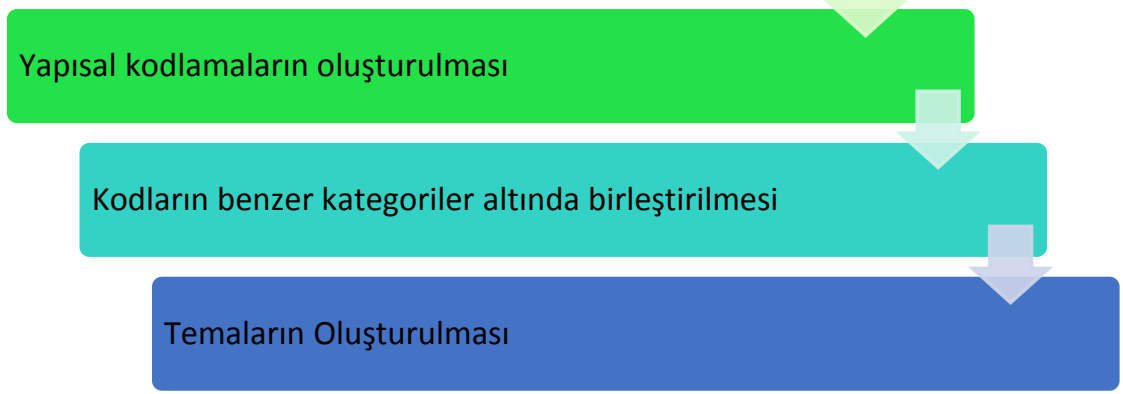

Şekil 1. İ̧̧erik Analizinde Takip Edilen İşlemler

Gözlemler gerçekleştirildiği günün sonunda araştırmacının gözlem raporları, ikinci araştırmacının gözlem raporları ve kamera kayıtları incelenerek bilgisayar ortamında temize çekilmiştir. Görüşmeler de gözlemlere benzer şekilde gerçekleştirildiği günün sonunda bilgisayar ortamında yazılı hale getirilmiştir. Öğrenci günlükleri ise haftalık olarak temize çekilerek bilgisayar ortamına kaydedilmiştir. Yazılı dokümanlar tamamlandıktan sonra ham veriler araştırmacı notları ile birlikte NVivo 11 Pro programına aktarılmıştır. Veriler bu programın aracılığı ile analiz edilmiştir. Öncelikle ham veriler tekrar tekrar okunarak kodlar oluşturulmuştur. Kodlar programa aktarılmış ve kodlamalar gerçekleştirilmiştir. Kodlamalar tamamlandıktan sonra kodlar arasındaki ilişkiler belirlenmeye çalışılmış ve benzer kodlar ortak kategoriler altında birleştirilmiştir. Bir sonraki aşamada benzer kategoriler ortak temalar altında birleştirilmiştir. Analizler arasındaki uyum yüzdelerinin hesaplanmasında

$$
\text { Uyum yüzdesi }=\frac{\text { Uyum miktarı }}{\text { uyum miktarı }+ \text { uyuşmazlık miktarı }} \times 100
$$

formülü kullanılmıştır. Uyum yüzdelerinin \%70 ve üzerinde olması durumunda güvenirliğin sağlanmış olduğu söylenebilir (Miles \& Huberman, 1994).

\section{Bulgular}

Öğrencilerin gözlem verilerine ait içerik analizi sonuçları Tablo 1'de verilmiştir. 
Tablo 1.

Gözlem Verilerine Ait Içerik Analizi Sonuçları

\begin{tabular}{llll}
\hline Tema & Kod & Merkez & Kırsal \\
\cline { 3 - 4 } & & $\mathbf{f}$ & $\mathbf{f}$ \\
\hline Motivasyon & ilgi & 30 & 29 \\
& heyecan & 25 & 27 \\
& istek & 32 & 30 \\
\hline Öğrenme Süreci & eğlenme & 32 & 29 \\
& bilgi paylaşımı & 23 & 21 \\
& katılım & 26 & 28 \\
& takip & 25 & 24 \\
& uzun dikkat süresi & 18 & 18 \\
\hline Sosyal Beceriler & söz alma & 16 & 14 \\
& dinleme & 25 & 26 \\
& yardımlaşma & 10 & 13 \\
\hline Olumsuz Davranışlar & rekabet & 2 & 4 \\
& hırs & 1 & 1 \\
& kaybetme & 1 & 2 \\
& gürültü & 4 & 5 \\
\hline
\end{tabular}

Tablo 1'de verilen gözlem verileri analiz sonuçlarına göre motivasyon temasında frekansların merkez bölgede derse ilgi için 30, heyecan için 25 ve istek için 32 olduğu ve kırsal bölgede derse ilgi için 29, heyecan için 27 ve istek için 30 olduğu belirlenmiştir. Öğrenme süreci temasında frekansların merkezde eğlenme için 32, bilgi paylaşımı 23, katılım için 26, takip için 25 ve uzun dikkat süresi için 18 olduğu ve kırsalda eğlenme için 29, bilgi paylaşımı için 21, katılım için 28, takip için 24 ve uzun dikkat süresi için 18 olduğu tespit edilmiştir. Sosyal beceriler temasında frekansların merkezde söz alarak düşünce ifade etme için 16, dinleme için 25 ve yardımlaşma için 10 olduğu ve kırsal bölgede söz alarak düşünce ifade etme için 14, dinleme için 26 ve yardımlaşma için 13 olduğu belirlenmiştir. Olumsuz davranışlar temasında frekansların merkezde rekabet için 2, hırs için 1, kaybetme için 1 ve gürültü için 4 olduğu ve kırsalda rekabet için 4 , hırs için 1, kaybetme için 2 ve gürültü için 5 olduğu tespit edilmiştir. Gözlem notlarından örnekler aşağıda verilmiştir:

K5-EO1: ... Yanındaki grup arkadaşı ile kendilerine gelen kartlardaki bilgileri birbirlerine okuyup aralarında hangi kutuya atmaları gerektiğini tartışıyorlar. Arkadaşının sorduğu soruları cevaplıyor. Ona kavramları açıklamaya çalışıyor. ...

M5-EO3: ... Grup arkadaşlarına bir şeyler anlatmaya çalışıyor. Bu sırada arkadaşlarından müsaade isteyerek söze başlıyor. ...

M5-EO-1: ... Yaptıkları hatalardan dolayı grup arkadaşları ile tartışıyor. Hareketlerini kontrol etmekte zorlanıyor. Sırasında ayağa kalkıp oturuyor. Diğer gruptaki arkadaşlarına sataşıyor. ...

Öğrencilerin hazırladıkları günlüklerden elde edilen verilerin içerik analizi sonuçları Tablo 2'de verilmiştir. 
Tablo 2.

Öğrencilerin Günlüklerine Ait Verilerin Içerik Analizi Sonuçları

\begin{tabular}{|c|c|c|c|}
\hline \multirow[t]{2}{*}{ Tema } & \multirow[t]{2}{*}{ Kod } & \multirow{2}{*}{$\begin{array}{l}\text { Merkez } \\
\mathrm{f}\end{array}$} & \multirow{2}{*}{$\begin{array}{l}\text { Kırsal } \\
f\end{array}$} \\
\hline & & & \\
\hline $\begin{array}{l}\text { Günlük Başına Düşen Öğrenilmiş } \\
\text { Kavram Ortalaması }\end{array}$ & Kavram & 3,2 & 2,7 \\
\hline \multirow[t]{10}{*}{ Duygu, Düşünce ve Tutumlar } & eğlenmek & 35 & 26 \\
\hline & istekli olmak & 27 & 21 \\
\hline & ilgi duymak & 30 & 32 \\
\hline & mutlu olmak & 17 & 14 \\
\hline & dersi sevmek & 20 & 17 \\
\hline & kaygılanmamak & 25 & 29 \\
\hline & heyecan duymak & 18 & 10 \\
\hline & meraklanmak & 11 & 11 \\
\hline & okulu sevmek & 13 & 17 \\
\hline & öğretmeni sevmek & 24 & 20 \\
\hline \multirow[t]{4}{*}{ Ders Süresince Sergilenen Davranışlar } & arkadaşlarla birliktelik & 19 & 18 \\
\hline & birlikte karar almak & 18 & 15 \\
\hline & bilgi/düşünce paylaşmak & 24 & 29 \\
\hline & hoşgörülü davranmak & 33 & 27 \\
\hline \multirow[t]{9}{*}{ Ders Sırasındaki İyi ve Kötü Yönler } & anlamak & 28 & 21 \\
\hline & akılda kalıcılık & 19 & 13 \\
\hline & kavramak & 17 & 14 \\
\hline & doğru yapmak & 17 & 21 \\
\hline & kazanmak & 7 & 9 \\
\hline & özgüven & 16 & 11 \\
\hline & kazanma hırsı & 6 & 9 \\
\hline & anlaşmazlık & 4 & 2 \\
\hline & sinirlenmek & 4 & - \\
\hline \multirow[t]{2}{*}{ Sonraki Ders İçin Öneriler } & aynı şekilde devam etmesi & 32 & 34 \\
\hline & grubun değişmesi & 4 & 2 \\
\hline
\end{tabular}

Tablo 2'de verilen analiz sonuçlarından görüldüğü üzere öğrencilerin günlüklerinde açıkladıkları kavramlar incelenmiş ve günlüklerde eksiksiz bir şeklide tam olarak açıklanan kavramların sayısı günlük sayısına bölünerek günlük başına düşen kavram sayısı belirlenmiştir. Buna göre öğrencilerin günlük başına öğrendikleri kavram sayısı merkez için 3,2 ve kırsal bölge için 2,7 olarak hesaplanmıştır. Duygu, düşünce ve tutumlar temasında merkezde eğlenme için frekansın 35, öğrenmeye istekli olma için 27, derse ve öğrenmeye ilgi için 30, mutlu olma için 17 dersi sevme için 20, kaygı hissetmeme için 25, heyecanlanma için 18 , merak duyma için 11 , okulu sevme için 13 ve öğretmeni sevme için 24 olduğu ve kırsalda eğlenme için frekansın 26, öğrenmeye istekli olma için 21, derse ve öğrenmeye ilgi için 32, mutlu olma için 14 dersi sevme için 17, kaygı hissetmeme için 29, heyecanlanma için 10, merak duyma için 11, okulu sevme için 17 ve öğretmeni sevme için 20 olduğu belirlenmiştir. Ders süresince sergilenen davranışlar temasında merkezde frekansların arkadaşlarla birliktelik için 19, birlikte karar alıp uygulama için 18, bilgi/düşünce paylaşımı için 24 ve hoşgörülü davranma için 33 olduğu ve kırsalda frekansların arkadaşlarla birliktelik için 18, birlikte karar alıp uygulama için 15, bilgi/düşünce paylaşımı için 29 ve hoşgörülü davranma için 27 olduğu belirlenmiştir. Ders sırasındaki iyi ve kötü yönler temasında merkezde frekansların anlama için 28, akılda kalıcılık için 19, kavrama için 17, doğru yapma için 17, kazanma için 7, özgüven için 16, kazanma hırsı için 6, anlaşmazlık için 4 ve sinirlenme için 4 olduğu ve kırsalda frekansların anlama için 21, akılda kalıcılık için 13, kavrama için 14, doğru yapma için 21, kazanma için 9, özgüven için 11, kazanma hırsı için 9 ve anlaşmazlık için 2 olduğu tespit edilmiştir. 
sonraki ders için öneriler temasında merkezde frekansların oyunların aynı şekilde devam etmesi için 32 ve grubunun değişmesi için 4 olduğu ve kırsalda frekansların oyunların aynı şekilde devam etmesi için 34 ve grubunun değişmesi için 2 olduğu tespit edilmiştir. Öğrencilerin günlüklerinden örnekler aşağıda verilmiştir:

K5-EO2: ... Çikolata yapmak çok eğlenceliydi ve lezzetliydi. Oyunlarda çok eğleniyorum ve doğru yapıyorum. Kazandığımız için çok mutluyum. ...

M5-EO1: ... Biliyorsun ilk günlerde $X$ ile sıkıntı yaşamıştık. Onun yüzünden oyunları kaybetmiştik. Ona çok kızıyordum ve hep kavga ediyorduk. Sana demiştim ya ona daha iyi davranacağım belki daha iyi olur ozaman diye. Ama artık hepsi bitti. $X$ isteyince çok da güzel öğreniyormuş. Biliyor musun bugün az daha yanlış yapacaktım ve $X$ beni uyardı. Başta anlaşamıyorduk ama artık en iyi arkadaşlarımdan biri. ...

M5-EO3: ... Fen dersini, okulu ve canım öğretmenimiz $X$ hocayı daha daha daha çok seviyorum. ...

K5-EO1: ... Bu dersi çok seviyorum çünkü bu üniteyi oyun oynayarak geçiriyoruz. Bence sonraki derslerde böyle geçsin hem eğleniyor hemde öğreniyoruz. ...

Öğrencilerin yönteme yönelik görüşlerini belirlemek amacıyla yapılan görüşmelerden elde edilen verilerin içerik analizi sonuçları Tablo 3'te verilmiştir.

Tablo 3.

Öğrencilerin Yönteme Yönelik Görüşlerine Ait Analiz Sonuçları

\begin{tabular}{|c|c|c|c|}
\hline \multirow[t]{2}{*}{ Tema } & \multirow[t]{2}{*}{ Kod } & \multirow{2}{*}{$\begin{array}{l}\text { Merkez } \\
\text { f }^{*}\end{array}$} & \multirow{2}{*}{$\begin{array}{l}\text { Kirsal } \\
f^{*}\end{array}$} \\
\hline & & & \\
\hline \multirow[t]{8}{*}{ Yöntemin Öğrenmeye Etkisi } & bilgi sağlama açısından yeterli & 3 & 3 \\
\hline & eğlenerek öğrenme & 2 & 3 \\
\hline & $\begin{array}{l}\text { öğretmenin konuyu anlatmasına } \\
\text { gerek olmaması }\end{array}$ & 3 & 1 \\
\hline & etkili öğrenme & 1 & 2 \\
\hline & daha kolay anlama & 1 & 1 \\
\hline & akılda kalıcı & 1 & 1 \\
\hline & bilişsel gelişim & 1 & - \\
\hline & bilgiyi dönüştürme & - & 2 \\
\hline \multirow[t]{6}{*}{ Sosyal Becerilere Etkisi } & arkadaşlık ilişkileri & 2 & 3 \\
\hline & birlikte çalışma & 2 & 2 \\
\hline & farklı düşüncelere saygı & 2 & 1 \\
\hline & görev paylaşımı & 1 & 1 \\
\hline & yardımlaşma & - & 2 \\
\hline & grup bilinci & 1 & 1 \\
\hline \multirow[t]{3}{*}{ Derse Yönelik Tutuma Etkisi } & dersi sevme & 2 & 3 \\
\hline & kaygı hissetmeme & 1 & 3 \\
\hline & öğrenme isteği & 1 & 2 \\
\hline
\end{tabular}


YILDIZ \& ŞiMŞEK - Çukurova Üniversitesi Eğitim Fakültesi Dergisi, 50(2), 2021, 1367-1396

\begin{tabular}{llll}
\hline Kişisel Gelişime Etkisi & $\begin{array}{l}\text { özgüven } \\
\text { bireysel çalışma }\end{array}$ & 1 & 2 \\
\hline Yöntemin Olumsuz Yönleri & olumsuz yönü yok & 3 & 1 \\
\hline $\begin{array}{l}\text { Yöntem Tekrar Uygulandığında } \\
\text { Dikkat Edilecek Durumlar }\end{array}$ & $\begin{array}{l}\text { günlük tekrarlar yapma } \\
\text { grup arkadaşlarının fikirlerini } \\
\text { alma }\end{array}$ & 2 & 3 \\
& $\begin{array}{l}\text { arkadaşlık ilişkilerine önem } \\
\text { verme }\end{array}$ & - \\
& arkadaşlara hoşgörülü davranma & 1 & 1 \\
& & - \\
\hline
\end{tabular}

*öğrenciler birden fazla görüş belirtmiştir.

Tablo 3'te verilen analiz sonuçlarına göre yöntemin öğrenmeye etkisi temasında merkezde EO yönteminin bilgi sağlama açısından yeterliliği için frekansın 3, eğlenerek öğrenme için 2, öğretmenin konuyu anlatmasına gerek olmaması için 3, etkili öğrenme için 1 , daha kolay anlama için 1, akılda kalıcı bilgi edinme için 1, bilişsel gelişim için 1 olduğu ve kırsalda EO yönteminin bilgi sağlama açısından yeterliliği için frekansın 3, eğlenerek öğrenme için 3, öğretmenin konuyu anlatmasına gerek olmaması için 1, etkili öğrenme için 2, daha kolay anlama için 1 ve akılda kalıcı bilgi edinme için 1 olduğu belirlenmiştir. Bunların yöntemin öğrenmeyi kolaylaştırması, kavramların sık tekrarlanması, bilgiyi farklı şekillerde organize etme ve bilgiyi dönüştürme durumlarından kaynaklandığı belirlenmiştir. Sosyal becerilere etkisi temasında merkezde arkadaşlık ilişkileri için frekansın 2, birlikte çalışma için 2, farklı düşüncelere saygı duyma için 2, görev paylaşımı için 1 ve grup bilinci için 1 olduğu ve kırsalda arkadaşlık ilişkileri için frekansın 3, birlikte çalışma için 2, farklı düşüncelere saygı duyma için 1, görev paylaşımı için 1, yardımlaşma için 2, grup bilinci için 1 olduğu tespit edilmiştir. Bunların grup arkadaşları arasındaki iletişimin yoğunluğundan ve birlikte karar alıp uygulama durumlarından kaynaklandığı belirlenmiştir. Derse yönelik tutuma etkisi temasında merkezde frekansların dersi sevme için 2, derste kaygı hissetmeme için 1, öğrenme isteği için 1 olduğu ve kırsalda frekansların dersi sevme için 3, derste kaygı hissetmeme için 3, öğrenme isteği için 2 olduğu tespit edilmiştir. Bunların heyecan duyma, yöntemin eğlenceli olması, zevkli olması ve merak uyandırıcı olması nedenlerinden kaynaklandı̆̆ı tespit edilmiştir. Kişisel gelişime etkisi temasında merkezde frekansların bireysel çalışma alışkanlığı için 1 olduğu ve kırsalda frekansların özgüven için 2 ve bireysel çalışma alışkanlığı için 1 olduğu belirlenmiştir. Bunların nedeninin başarma duygusu olduğu belirlenmiştir. Öğrencilerin tamamının yöntemin herhangi bir olumsuz yönünün olmadığı görüşünde olduğu tespit edilmiştir. Yöntem tekrar uygulandığında dikkat edilecek durumlar temasında merkezde frekansların günlük tekrar yapma için 2, grup arkadaşlarının fikirlerini sorma için 1 ve arkadaşlarına hoşgörülü davranma için 1 olduğu ve kırsalda frekansların günlük tekrar yapma için 1 ve arkadaşlık ilişkilerine önem verme için 1 olduğu belirlenmiştir. Öğrencilerin verdikleri cevaplardan örnekler aşağıda verilmiştir:

K5-EO1: ... Hocam mesela korkarım derslerden kötü alırım diye ama fende hiç böyle bir duygum yok. Sanki fen hayatımmış gibi geliyor. Eskiden fende de böyleydi ama hocamızın bizim için hazırladığı oyunları oynadıktan sonra dediğim gibi sanki fen hayatım oldu. ...

M5-EO3: ... Öğrenme isteğim çok arttı. Mesela artık çok öğrenmek istiyorum. Mesela diyelim bir konu var daha çok öğrenmek istiyorum tanımak istiyorum. Daha fazla fen çalışıyorum. Ödevim olmasa bile çalışıyorum. ...

K5-EO2: ... Anneme hep sorardım: O neydi? Bu neydi? Şu neydi? Biliyor musun? Şimdi kendim tek çalışabiliyorum. Oyunda yaptıklarımız hep aklımda kalıyor. Çalışırken ben de onları kullanarak çalışıyorum. ... 
YILDIZ \& ŞIMŞEK - Çukurova Üniversitesi Eğitim Fakültesi Dergisi, 50(2), 2021, 1367-1396

Öğrencilerin EO yönteminin yaşadıkları öğrenme problemlerinin çözümüne yönelik görüşlerini belirlemek amacıyla yapılan görüşmelerden elde edilen verilerin içerik analizi sonuçları Tablo 4'te verilmiştir.

Tablo 4.

Öğrencilerin EO Yönteminin Yaşadıkları Öğrenme Probleminin Çözümüne Yönelik Görüşlerine Ait Analiz Sonuçları

\begin{tabular}{|c|c|c|c|}
\hline \multirow[t]{2}{*}{ Tema } & \multirow[t]{2}{*}{ Kod } & \multirow{2}{*}{$\begin{array}{l}\text { Merkez } \\
\mathbf{f}^{*}\end{array}$} & \multirow{2}{*}{$\begin{array}{l}\text { Kirsal } \\
f^{*}\end{array}$} \\
\hline & & & \\
\hline $\begin{array}{l}\text { Öğrenme Problemleri } \\
\text { Yaşanan Konuların } \\
\text { Öğretiminde Uygulanması }\end{array}$ & uygulanmasına istekli & 3 & 3 \\
\hline \multirow{2}{*}{$\begin{array}{l}\text { Öğrenme Üzerindeki } \\
\text { Etkileri }\end{array}$} & başarıyı artırmada etkili & 3 & 3 \\
\hline & kalıcılığı artırmada etkili & 3 & 3 \\
\hline \multirow[t]{2}{*}{$\begin{array}{l}\text { Duyuşsal Faktörler } \\
\text { Üzerindeki Etkileri }\end{array}$} & $\begin{array}{l}\text { motivasyonu artırmada } \\
\text { etkili }\end{array}$ & 3 & 3 \\
\hline & kaygıyı azaltmada etkili & 3 & 3 \\
\hline \multirow{10}{*}{$\begin{array}{l}\text { Öğrenme Problemlerinin } \\
\text { Çözümüne Etkilerinin } \\
\text { Nedenleri }\end{array}$} & ilgi çekici & 2 & 3 \\
\hline & eğlenceli & 2 & 3 \\
\hline & baskı hissetmeme & 3 & 1 \\
\hline & kolay öğrenme & 2 & 2 \\
\hline & bilgilerin sık tekrarı & 1 & 2 \\
\hline & farklı şekillerde tekrarlama & 1 & 2 \\
\hline & merak uyandırıcı & 2 & 1 \\
\hline & endişelenmeme & 2 & 1 \\
\hline & bilgileri organize etme & 1 & 1 \\
\hline & $\begin{array}{l}\text { bilgiyi yeni forma } \\
\text { dönüştürme }\end{array}$ & 1 & 1 \\
\hline
\end{tabular}

\section{*̈̈̆renciler birden fazla görüş belirtmiştir.}

Tablo 4'te verilen analiz sonuçlarından görüldüğü üzere öğrencilerin tamamı öğrenme problemleri yaşanan konuların öğretiminde EO yönteminin kullanılmasını istemektedir. Öğrenme üzerindeki etkileri temasında frekansların merkezde başarıyı artırmada etkililiği için 3 ve kalıcılığı artırmada etkililiği için 3 olduğu ve kırsalda başarıyı artırmada etkililiği için 3 ve kalıcılığı artırmada etkililiği için 3 olduğu belirlenmiştir. Duyuşsal faktörler üzerindeki etkileri temasında frekansların merkezde motivasyonu artırmada etkililiği için 3 ve kaygıyı azaltmada etkililiği için 3 olduğu ve kırsalda motivasyonu artırmada etkililiği için 3 ve kaygıyı azaltmada etkililiği için 3 olduğu tespit edilmiştir. Öğrenme problemlerinin çözümüne etkilerinin nedenleri temasında frekansların merkezde yöntemin ilgi çekici olması için 2, eğlenceli olması için 2, merak uyandırıcı olması için 2, yöntemde baskı hissetmeme için 3, kolay öğrenme için 2, bilgileri sık tekrar etme için 1, farklı şekillerde tekrarlama için 1, endişelenmeme için 2, bilgileri organize etme için 1 ve bilgiyi yeni forma dönüştürme için 1 olduğu ve kırsalda yöntemin ilgi çekici olması için 3, eğlenceli olması için 3, merak uyandırıcı olması için 1, yöntemde baskı hissetmeme için 1, kolay öğrenme için 2, bilgileri sık tekrar etme için 2, farklı şekillerde tekrarlama için 2, endişelenmeme 
için 1 , bilgileri organize etme için 1 ve bilgiyi yeni forma dönüştürme için 1 olduğu belirlenmiştir. Öğrencilerin verdikleri cevaplardan örnekler aşağıda verilmiştir:

K5-EO2: ... Bence başarım daha da arttı. Çünkü sevdiğim eğlendiğim zaman dersimi daha dikkatli yapıyorum. Eve gittiğimde derslerime daha çok çalışmak istiyorum. Daha güzel ögreniyorum. ...

K5-EO3: ... Oyunlar çok eğlenceli. Derslerde hiç sıkılmadım. Hep daha çok şey öğrenmek istedim. Öğrendikçe oyunlarda daha başarılı olacağımı biliyordum. Onun için problem yaşadığım konuda da bence işe yaradı.

M5-EO1: ... Mesela bir soru sorulunca öğretmen anlatmış olsa çok zor aklıma geliyor. Düşünüyorum iyice zorlanıyorum öyle aklıma geliyor. Hatta aklıma gelmiyor da. Ama oyunda yaptıklarımız hep aklımda kalıyor. Soru gelince hemen çabucak cevap verebiliyorum.

\section{Sonuç ve Tartışma}

Öğrencilerin, öğrenme problemleri yaşadıkları "Madde ve Değişim” konusunun öğretiminde uygulanan EO yöntemine yönelik algılarını belirlemek amacıyla yapılan bu araştırmada süreç boyunca öğrenci davranışları gözlenmiş, öğrenciler günlük yazmış, öğrencilerle görüşme yapıımış ve süreçte elde edilen veriler içerik analizi yöntemiyle analiz edilmiştir. Elde edilen sonuçlar aşağıda sunulmuştur.

Öğrencilerin EO yöntemini bilgi sağlama açısından yeterli bulduğu, bu yöntemle daha etkili ve kolay öğrendiği, oyunların daha iyi anlamalarını sağladığı, anlamlı öğrenmeler gerçekleştirdiği, bilgilerin sık tekrarlanması, oyunu kazanmak için bilgileri çeşitli şekillerde organize etme ve dönüştürme nedenleriyle yöntemin başarıyı artırdığı belirlenmiştir. Alanyazında beşinci sınıf düzeyinde yapılan farklı araştırmalarda elde edilen sonuçlar bu araştırmadan elde edilen yöntemin başarı üzerinde etkili olduğu sonuçlarını destekler niteliktedir (Anderson, 2008; Aymen-Peker, 2018; Çelik, 2017; Dowling, 2012; Koka, 2018). Neimeyer (2006) tarafından yapılan araştırmada elde edilen oyunlarla öğretimin başarıya etkisinin olmadığı sonucu bu araştırmanın sonucu ile ters düşmektedir. İki araştırmanın sonuçlarının farklılaşmasında araştırmada benimsenen yöntemlerin, veri toplama ve analiz şekillerinin farklılığının etkili olduğu söylenebilir. Bu araştırmada nitel desen benimsenmiş, veriler günlük, gözlem, görüşme ile toplanmış, içerik analizi ile analiz edilmiş ve Neimeyer (2006) tarafından yapılan araştırmada nicel desen benimsenmiş, veriler başarı testi ile toplanmış, anlamlıık testleri ile analiz edilmiştir. Dolayısıyla EO yönteminin öğrenmede ve akademik başarıyı geliştirmede etkili olduğu sonucu bu araştırmada öğrencilerin algılarına bağlı iken Neimeyer (2006)'nın sonuçlarında anlamlılık analizlerine bağlı olduğundan farklılaşma gözlenmiş olabilir.

Öğrencilerin oyun sırasında kavramları öğrenmeleri sayesinde öğretmenlerinin konuyu anlatmasına gerek kalmadan EO yöntemi ile etkili bir şekilde öğrendikleri ve kavram öğrenme oranlarının yüksek olduğu bulunmuştur. Benzer şekilde beşinci sınıf düzeyinde (Aymen-Peker, 2018; Dowling, 2012) yedinci sınıf düzeyinde (Boyce, 2016) ve sekizinci sınıf düzeyinde (Harvey, 2018) yapılan araştırmalarda eğitsel oyunların kavram öğrenmede etkili olduğu belirtilmiştir.

EO yönteminin oyunların eğlenceli, ilgi çekici, zevkli ve merak uyandırıcı olması nedeniyle öğrenme motivasyonunu artırdığı, kendilerini mutlu hissettikleri, öğrenciler için eğlenerek öğrenmeyi sağladığı ve oyunlar sırasında öğrencilerin derse ve öğrenmeye karşı ilgili ve istekli oldukları tespit edilmiştir. Bu araştırmadan elde edilen sonuçlar alanyazında yedinci sınıf düzeyinde (Say \& Bağ, 2017; Toprac, 2008) ve sekizinci sınıf düzeyinde (Bressler, 2014; Nunes, Soares \& Catarino, 2018) yapılan araştırmalarda elde edilen öğrenme motivasyonunu geliştirmede etkili olduğu sonuçlarıyla uyumludur. Atwood-Blaine (2015), tarafından yapılan araştırmada oyunlarla öğretimin yedinci sınıf öğrencilerinin motivasyonu üzerinde etkili olmadığı yönündeki araştırma sonucu ile ters düşmektedir. Bu durum araştırmaların örneklemleri, oyun türleri ve uygulama süreleri arasındaki farklardan kaynaklandığı söylenebilir. Beşinci sınıf öğrencilerinin gelişim özellikleri dikkate alındığında oyunlara daha fazla ilgi gösterdiği ve yedinci 
sınıf öğrencilerinin somut işlemler döneminden soyut işlemler dönemine geçiş evresinde olduklarından oyunlara beşinci sınıf öğrencileri kadar ilgi göstermediği söylenebilir.

EO yönteminin öğrencilerin konuyu, dersi, öğretmeni ve okulu daha fazla sevmelerini sağladığı belirlenmiştir. $\mathrm{Bu}$ araştırmadan elde edilen sonuçlar alanyazında ortaokul seviyesinde yapılan araştırmalarda elde edilen oyunlarla öğretimin öğrencilerin tutumlarını geliştirmede etkili olduğu sonucu ile uyumludur (Çelik, 2017; Eltem, 2018; Gürpınar, 2017; Nunes, Soares \& Catarino, 2018; Yeşilkaya, 2013; Yıldız, Şimşek \& Ağdaş, 2018). Benzer şekilde beşinci sınıf öğrencileri ile çalışan Zheng ve Hiller (2012), oyunlarla öğretimin öğrencilerin tutumları üzerinde etkili olmadığı sonucuna ulaşmıştır. Benzer örneklem gruplarında çalışan iki araştırmanın sonucunun farklılaşmasının nedeni kullanılan oyun türlerinin farklı olması olabilir.

Öğrencilerin oyunlar sırasında normalde sınıf ortamında olan baskı ve endişelerini hissetmemeleri nedeniyle EO yönteminin öğrenme kaygııını azalttığı belirlenmiştir. Bu araştırmadan elde edilen sonuçlar altıncı sınıf düzeyinde uygulanan eğitsel oyun yönteminin öğrenme kaygısını azaltmada etkili olduğunu belirten araştırma sonuçları ile uyumludur (Yıldız, Şimşek, \& Aras, 2017).

EO yönteminin arkadaşlık ilişkilerini, görev paylaşımı, birlikte çalışma ve öğrenme, söz alarak düşüncelerini ifade etme, öğretmenlerini ve arkadaşlarını dinleme, birbirlerinin düşüncelerine saygı duyma, bilgi paylaşımı, yardımlaşma, grup olma bilinci, özgüven, birlikte karar alma ve uygulama becerilerini geliştirdiği belirlenmiştir. Öğrencilerde kazanma hırsı, anlaşmazlık ve rekabet gibi olumsuz davranışların olduğu, ancak öğrencilerin bu durumun farkında oldukları ve düzeltmek için çaba gösterdikleri belirlenmiştir. Benzer şekilde ortaokul düzeyinde çalışılan araştırmalar EO yönteminin öğrencilerin sosyal becerilerini (Yıldız, Şimşek, \& Aras, 2017) ve birlikte çalışma becerilerini (Bressler, 2014) geliştirdiği sonucuna ulaşmışır. Lisans düzeyinde çalışan Fanetti (2011), bu araştırma sonucuna zıt olarak EO yönteminin sosyal beceri gelişiminde etkili olmadığı sonucuna ulaşmıştır. Gerçek ortam oyunlarının kullanıldığı bu araştırmanın sonucuyla video oyunlarının kullanıldığı araştırmanın sonuçlarının birbiriyle çelişmesi araştırma örneklemlerinin ve oyun türlerinin farkııı̆ı̆ından kaynaklanıyor olabilir. Gerçek ortamda oynatılan oyunların video oyunlarına göre öğrencilerin birbirleriyle daha fazla etkileşimde bulunmasını ve iletişimlerinin daha fazla olmasını sağladığı ve bu nedenle öğrencilerin sosyal becerilerini geliştirmede daha etkili olduğu söylenebilir.

Beşinci sınıf düzeyinde merkez ve kırsal bölgelerden günlük, gözlem ve görüşmelerle altı öğrencinden veri alınarak gerçekleştirilen bu araştırma "Madde ve Değişim" ünitesinde 26 ders saatinde tamamlanmıştır. Öğrencilerin EO yöntemine yönelik algılarının olumlu olduğu, oyunlarla öğretimin başarı, motivasyon, tutum, kaygı ve sosyal beceriler üzerinde etkili olduğu ve öğrenme problemlerine çözüm olduğu tespit edildiğinden bu yöntemin farklı konuların öğretiminde kullanılması eğitimciler açısından yararlı olabilir. EO yönteminin farklı sınıf düzeylerinde uygulanabilir. Başarı, motivasyon, tutum veya sosyal beceri düzeyleri düşük olan öğrencilerin olduğu gruplarda uygulanabilir. Kaygı düzeyi yüksek olan öğrencilerin bulunduğu sınıflarda uygulanması faydalı olabilir.

\section{References}

Aamondt, S., \& Wang, S. (2011). Welcome to your child's brain: How the mind grows from conception to college. USA: Bloomsbury.

Akandere, M. (2012). Educational school games. Ankara: Nobel.

Anderson, J. L. (2008). The kids got game: Computer/video games, gender and learning outcomes in science classrooms. Doctoral Dissertation, Boston College, USA.

Atwood-Blaine, D. (2015). The effect of playing a science center-based mobile game: Affective outcomes and gender differences. (Unpublished doctoral dissertation). Retrieved from http://hdl.handle.net/1808/21680 
YILDIZ \& ŞIMŞEK - Çukurova Üniversitesi Eğitim Fakültesi Dergisi, 50(2), 2021, 1367-1396

Aymen Peker, E. (2018). Evaluation of teaching the unit of 'Let's Travel and Learn About The Living World' for 5th grades with classic educational games and educational games supported with technology (Unpublished doctoral dissertation). Ondokuz Mayıs University, Turkey.

Bilen, M. (2002). Plandan Uygulamaya Öğretim. Ankara: Anı Yayıncılık.

Boyce, D. A. (2016). The effect of the video game quizlet on the acquisition of science vocabulary for children with learning disabilities (Unpublished master thesis). Rowan University, USA.

Bressler, D. M. (2014). Is it all in the game? flow experience and scientific practices during an INPLACE mobile game (Unpublished doctoral dissertation). Lehigh University, USA.

Buluş Kırıkkaya, E., \& Güllü, D. (2008). İlköğretim beşinci sınıf öğrencilerinin ISı - sıcaklık ve buharlaşma kaynama konularındaki kavram yanılgıları. Illköğretim Online, 7(1), 15-27.

Çelik, O. (2017). Practicing educational games on 5th class students prepared for the 'Classifying LivingThings' unit impression on education manner of conduct and academic success (Unpublished master thesis). Erzincan University, Turkey.

Demir, M., \& Kurt, H. (2015). Game-based learning-teaching approaches. G. Ekici (Ed.), Learningteaching approaches with examples of activities-II in (pp.330-375). Ankara: Pegem Academy.

Demirel, Ö. (1999). The art of teaching from planning to evaluationAnkara: Pegem A publications.

Dowling, A. (2012). Rules of the game: Effects of a game-based metaphor on instructional activity design and the use of student mentors on learning outcomes in a middle school general science class (Unpublished doctoral dissertation). West Virginia University, USA.

Dönmez, N. B. (1992). Game book. İstanbul: Demet.

Eltem, Ö. (2018). Using the educational games in teaching structure and properties of the material unit in science (Unpublished master thesis). Eskişehir Osmangazi University, Turkey.

Espinoza Morales, C. (2017). Learning electron transport chain process in photosynthesis using video and serious game (Unpublished doctoral dissertation). Purdue University, USA.

Fanetti, T. M. (2011). The effect of problem-solving video games on the science reasoning skills of college students (Unpublished doctoral dissertation). Purdue University, USA.

Fleer, M. (2014). Theorling play in the early years. USA: Cambridge University Press.

Folta, E. E. (2010). Investigating the impact on student learning and outdoor science interest through modular serious educational games: A design-based research study (Unpublished doctoral dissertation). North Carolina State University, USA.

Fraenkel, J. R., Wallen, N. E., \& Hyun, H. H. (2011). How to design and evaluate research in education (8 th ed.). New York: McGraw-Hill.

Gençer, S. (2017). The effect of 'electricity in life' unit of 7th grade in primary schools to student success which has been prepared with educational games (Unpublished master thesis). Amasya University, Turkey.

Gillham, B. (2000). Case study research methods. London: Continuum.

Glesne, C. (2011). Becoming qualitative researchers: An introduction (4th ed.). Boston, MA: Pearson.

Gros, B. (2007). Digital games in education: The design of games based learning environments. Journal of Research on Technology in Education, 40, 23-39.

Gürpınar, C. (2017). The impact of pedagogical play-assisted teaching applications on learning outputs in science teaching (Unpublished mastrer thesis). Kırıkkale University, Turkey.

Habraken, C. L. (2004). Integrating into chemistry teaching today's student's visuospatial talents and skills, and the teaching of today's chemistry's graphical language. Journal of Science Education and Technology, 13(1), 89-94. 
YILDIZ \& ŞIMŞEK - Çukurova Üniversitesi Eğitim Fakültesi Dergisi, 50(2), 2021, 1367-1396

Harvey, M. M. (2018). Video games and virtual reality as classroom literature: Thoughts, experiences, and learning with 8th grade middle school students (Unpublished doctoral dissertation). University of New Mexico, USA.

Hazar, M. (2006). Game education in physical education and sport. Ankara: Tubitay.

Huang, T. (2016). The effects of types of reflective scaffolding and language proficiency on the acquisition of physics knowledge in a game-based learning environment (Unpublished doctoral dissertation). New York University, USA.

Johnson, R.B., \& Christensen, L. (2014). Educational research: Quantitative, qualitative, and mixed approaches (5th ed.). Thousand Oaks, CA: Sage.

Koka, V. (2018). The effect of computer aided educational games used in social sciences course (Unpublished master thesis). İnönü University, Turkey.

MacKenzie, J. R. (2014). Mıllennial interıor design students' perceptions concerning game-based learning in a lighting design course (Unpublished master thesis). Colorado State University, USA.

Malone, T. W., Lepper, M. R., Snow, R. E., \& Farr, M. J. (1987). Making learning fun: A taxonomy of intrinsic motivations for learning. Hillside, NJ: Lawrence Erlbaum Associates.

Mcmillan, J. H., \& Schumacher, S. (2006). Research in education: Evidence-Based inquiry. (6th ed.). Boston, MA: Allyn and Bacon.

Michael, D. \& Chen, S. (2006) Serious games: Games that educate, train, and inform. Boston, MA: Thomson Course Technology.

Miles, M. B. \& Huberman, A. M. (1994). Qualitative data analysis: an expande sourcebook (2nd edition). Thousand Oaks, CA: Sage.

Neuman, W. L. (2014). Social research methods: Qualitative and quantitative approaches (7th ed.). Essex: Pearson.

Nunes, P. S., Soares, A. A., \& Catarino, P. (2018). Efeitos da construção de um jogo educativo de matemática nas atitudes e aprendizagem alunos: estudo de caso (Effects of the construction of an educational mathematics game on students' attitudes and learning: case study). Revista Iberoamericana sobre Calidad, Eficacia y Cambio en Educación, 16(4), 5-21.

Özgür, H. (2000). Primary school period's children's interest for playgrounds (Unpublished master thesis). Hacettepe University, Turkey.

Pehlivan, H. (2014). Game and learning. Ankara: Anı.

Peng, L. (2009). Digital science games' impact on sixth and eighth graders' perceptions of science (Unpublished doctoral dissertation). Rhodes University, USA.

Rieber, L., Luke, N., \& Smith, J. (1998). Project KID DESIGNER: Constructivism through play.

Say, S., \& Bağ H. (2017). The evaluation of the effect of a newly designed computer game on 7th grade students' motivation towards science and aggression. EURASIA Journal of Mathematics Science and Technology Education, 13(8), 5379-5393. doi. 10.12973/eurasia.2017.00831a

Squire, K., \& Jenkins, H. (2003). Harnessing the power of games in education. Insight, 3, 5-33.

Stewart, P. M., Jr. (2013). Learning the rules of the game: The nature of game and classroom supports when using a concept-integrated digital physics game in the middle school science classroom (Unpublished doctoral dissertation). Columbia University, USA.

Şentürk, C. (2020). The effects of game based scıence learnıng experıences on academıc achıevement, retentıon, attıtudes and learnıng process. Journal of National Education, 49(227), 159-194.

Toprac, P. K. (2008). The effects of a problem -based learning digital game on continuing motivation to learn science (Unpublished doctoral dissertation). The University of Texas, USA 
YILDIZ \& ŞiMŞEK - Çukurova Üniversitesi Eğitim Fakültesi Dergisi, 50(2), 2021, 1367-1396

Yeşilkaya, i. (2013). 7th grade social science course, teaching the unit of 'science in time' by using the educational game method (Unpublished master thesis). İnönü University, Turkey.

Yıldız, E., Şimşek, Ü., \& Ağdaş, H. (2018). The effects of educational game-ıntegrated group research method on academic achievement, attitude towards school, and retention of knowledge in teaching regulatory system. Journal of Turkish Science Education, 15 (3), 91-105.

Yıldız, E., Şimşek, Ü., \& Aras, H. (2016). The effect of the educational game method on academic achievement and motivation towards science learning in teaching of circulatory system. Mustafa Kemal University Journal of Graduate School of Social Sciences, 13(36), 20-32.

Yıldız, E., Şimşek, Ü., \& Aras, H. (2017). The effect of the educational game method on students' social skills, attitude towards the school, and sciences learning anxiety. Journal of Necatibey Education Faculty, 11(1), 381-390.

Yin, R. K. (2003). Applications of Case Study Research. Sage.

Zheng, M., \& Hiller, A. S. (2012). Fifth graders' flow experience in a digital game-based science learning environment. International Journal of Virtual and Personal Learning Environments, 5(2), 69-86.

Araştırma Erzurum ì Milli Eğitim Müdürlüğünün 06.10.2017 tarihli ve 36648235-605.01.E.16089927 nolu izni kapsamında gerçekleştirilmiştir. Araştırmanın gerçekleştirildiği okul müdürüne ve sınıfın fen bilimleri öğretmenine araştırma onay formu imzalatılmıştır. Atatürk Üniversitesi Sosyal ve Beşeri Bilimler Etik Kurulu'nun 26.10.2016 tarih ve 48553601-000-E.1600268066 sayılı belgesi, araştırmada "Bilimsel Araştırma ve Yayın Etiğine Aykırı Eylemler"den hiçbirinin gerçekleştirilmediğini göstermektedir. 